

\section{DISCLAIMER}

This information was prepared as an account of work sponsored by an agency of the U.S. Government. Neither the U.S. Government nor any agency thereof, nor any of their employees, makes any warranty, expressed or implied, or assumes any legal liability or responsibility for the accuracy, completeness, or usefulness, of any information, apparatus, product, or process disclosed, or represents that its use would not infringe privately owned rights. References herein to any specific commercial product, process, or service by trade name, trade mark, manufacturer, or otherwise, does not necessarily constitute or imply its endorsement, recommendation, or favoring by the U.S. Government or any agency thereof. The views and opinions of authors expressed herein do not necessarily state or reflect those of the U.S. Government or any agency thereof. 


\title{
An Integrated Energy Systems Prototype Human- System Interface for a Steam Extraction Loop System to Support Joint Electricity-Hydrogen Flexible Operations
}

\author{
Thomas Ulrich \\ Roger Lew \\ Torrey Mortenson \\ Jooyoung Park \\ Heather Medema \\ Ronald Boring
}

March 2020

Prepared for the

U.S. Department of Energy

Office of Nuclear Energy 


\section{SUMMARY}

Due to increasing economic competition from renewables and combined-cycle natural gas plants, nuclear power plants are looking toward flexible operations to enhance their cost competitiveness. The Integrated Energy Systems project under the Light Water Reactor Sustainability program of the U.S. Department of Energy focuses on joint electricity-hydrogen flexible operations. Joint electricity-hydrogen flexible operations entail the nuclear power plant diverting thermal energy via main steam to a hydrogen production plant located nearby. The steam serves to enhance the efficiency of the hydrogen production. Furthermore, high temperature electrolysis requires a large amount of electricity, which the plant can also provide. The plant provides steam and electricity to the hydrogen plant throughout the day, but during peak demand hours the nuclear power plant returns to solely providing electricity to meet the high demand. Through this flexible concept of operations, the plant can optimize the thermal energy it produces without having to maneuver the power of the plant.

This report documents the human factors process to design and develop a prototype humansystem interface for the steam extraction loop that serves as the conduit between the nuclear power plant and the adjacent hydrogen plant. The design process followed the human factors guidelines set by NUREG-0711, Human Factors Engineering Program Review Model (O'Hara, Higgins, \& Fleger, 2012), and expanded upon by the Guideline for Operational Nuclear Usability and Knowledge Elicitation (GONUKE; Boring, Ulrich, Joe, \& Lew, 2015; Boring, Lew, \& Ulrich, 2016). The design process entailed operator interviews to determine the concept of operations for the steam extraction loop, a review and adaptation of digital interface design concepts developed by the team in prior projects, an iterative design process, and reviews conducted by both operators and human factors experts.

Several versions of the prototype human-system interface were developed. Operators were interviewed to determine what design features they found useful and would like to see in the interface. The design underwent a review by human factors experts against NUREG-0700, Human Interface Design Review Guidelines (U.S. Nuclear Regulatory Commission, 2019), to ensure compliance with the latest human factors standards for digital interfaces in nuclear applications. The design was then prototyped as a functional windows-based application integrated with the Generic Pressurized Water Reactor simulator modified to include the steam extraction loop. The simulation is supported by the Human Systems Simulation Laboratory at Idaho National Laboratory, which supports operator-in-the-loop testing.

This is an ongoing project and the next phase of the project entails performing an operator-inthe-loop usability study to evaluate the interface and examine the proposed concept of operations to extraction steam from the nuclear power plant for delivery to the coupled hydrogen production plant. 


\section{Table of Contents}

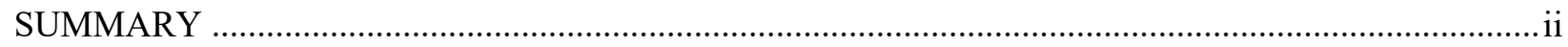

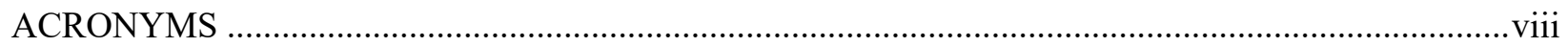

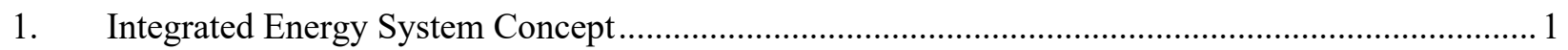

1.1 Market Challenges for Nuclear Power .......................................................................... 1

1.2 Joint Electricity-Hydrogen Flexible Operations.............................................................. 2

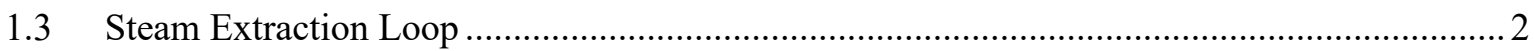

1.3.1 Steam Extraction Loop Operations ……............................................................ 3

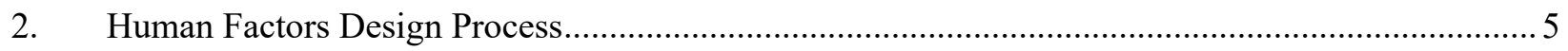

2.1 Step 1-Obtain Background and Engineering Documents ............................................. 6

2.2 Step 2 - Functional Requirements Analysis................................................................. 7

2.3 Step 3 - Determine the General Display Layout ............................................................. 10

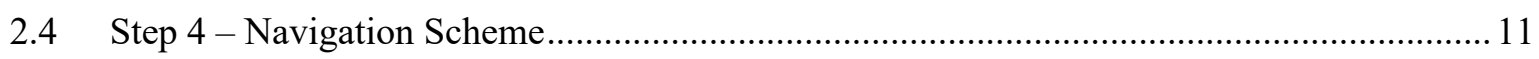

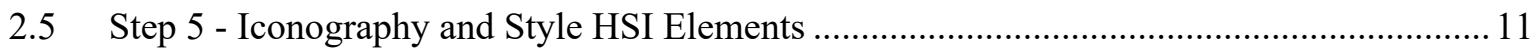

2.5.1 Prior Work Design Concepts ....................................................................................... 11

2.5.2 Additional Design Concepts Considered for the Steam Extraction Loop HSI ......... 14

2.6 Step 6 - Iterative Prototype Development....................................................................... 15

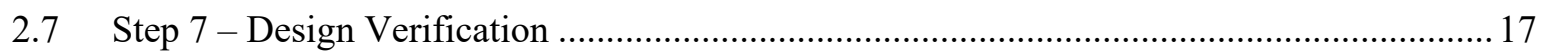

2.7.1 Expert Review .......................................................................... 17

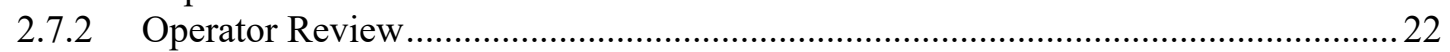

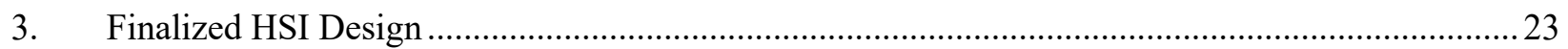

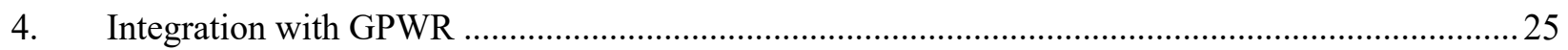

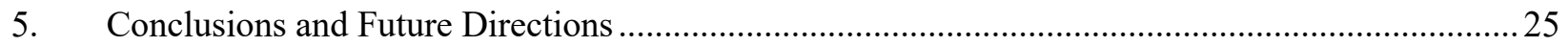

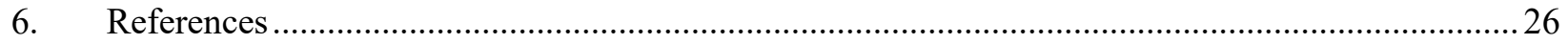




\section{FIGURES}

Figure 1. Steam Extraction Loop piping and instrumentation diagram for the current design.

Figure 2. NUREG-0711 activities organized by four phases. The items in blue are additions provided by GONUKE.

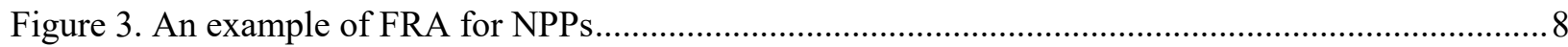

Figure 4. Display Layout for indication displays used for the steam extraction loop................................10

Figure 5. Turbine Control System Overview Display ............................................................................... 12

Figure 6. Computerized Operator Support System Overview display ....................................................13

Figure 7. Proposed steam extraction loop Interface design concepts..................................................... 15

Figure 8. Initial steam extraction loop indication display. ..................................................................... 16

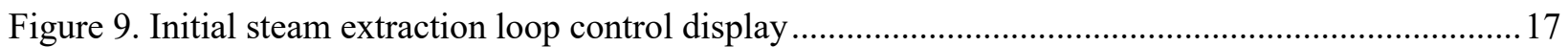

Figure 10. Finalized design of the steam extraction loop indication display incorporating the operator and expert reviews.

Figure 11. Finalized design of the steam extraction loop control displays incorporating the operator and expert reviews. The top display pertains to the main controls and the bottom display contains the controls for isolating the steam extraction loop. 


\section{TABLES}

Table 1. NUREG-0700, Revision 3, static design guidelines arranged by section.................................. 18

Table 2. NUREG-0700, Revision 3, dynamic design guidelines arranged by section..............................18

Table 3. Example results of the NUREG-0700 guideline review of the SEL HSI...................................20 


\section{ACRONYMS}

$\begin{array}{ll}\text { AAM } & \text { Automatic-AND-Manual } \\ \text { ANIME } & \text { Advanced Nuclear Interface Modeling Environment } \\ \text { AOM } & \text { Automatic-OR-Manual } \\ \text { AXM } & \text { Automatic-XOR-Manual } \\ \text { COSS } & \text { Computerized Operator Support Systems } \\ \text { DOE } & \text { Department of Energy } \\ \text { EIA } & \text { Energy Information Administration } \\ \text { FA } & \text { Function Allocation } \\ \text { FAA } & \text { Functional Allocation Analysis } \\ \text { FRA } & \text { Functional Requirements Analysis } \\ \text { GPWR } & \text { Generic Pressurized Water Reactor } \\ \text { HFE } & \text { Human Factors Engineering } \\ \text { HSI } & \text { Human Systems Interface } \\ \text { HSSL } & \text { Human System Simulation Laboratory } \\ \text { HTSE } & \text { High Temperature Steam Electrolysis } \\ \text { HX } & \text { Heat Exchanger } \\ \text { IES } & \text { Integrated Energy Systems } \\ \text { INL } & \text { Idaho National Laboratory } \\ \text { LWRS } & \text { Light Water Reactor Sustainability Program } \\ \text { NPP } & \text { Nuclear Power Plant } \\ \text { NRC } & \text { Nuclear Regulatory Commission } \\ \text { P \& ID } & \text { Piping and Instrumentation Design } \\ \text { SEL } & \text { Steam Extraction Loop } \\ \text { TA } & \text { Task Analysis } \\ \text { TCS } & \text { Turbine Control System } \\ \text { TEDS } & \text { Thermal Energy Dispatch System } \\ \end{array}$




\section{An Integrated Energy Systems Prototype Human- System Interface for a Steam Extraction Loop System to Support Joint Electricity-Hydrogen Flexible Operations}

\section{Integrated Energy System Concept}

This report describes a fully integrated human factors project demonstrating a joint electricityhydrogen capability, which demonstrates the process for performing nuclear human factors for novel and unprecedented systems in nuclear. Specifically, this paper provides the process for nuclear human factors activities within the context of an integrated energy systems use case. The use case project described here is being undertaken by the Light Water Reactor Sustainability (LWRS) Program of the U.S. Department of Energy (DOE). Specifically, the Idaho National Laboratory (INL) is using their Human Systems Simulation Laboratory (HSSL) to support the engineering, human factors, and validation through operator studies of the new steam extraction loop (SEL) to support the coupled hydrogen production.

\subsection{Market Challenges for Nuclear Power}

Within the last seven years, eight U.S. nuclear power plants (NPPs) have shut down and three more are scheduled to shut down by 2022. The 98 remaining NPPs still operating account for roughly $20 \%$ of total electricity production in the U.S. These remaining NPPs are increasingly challenged to compete in the wholesale electricity markets due to emerging cheaper forms of energy. In particular, natural gas combined-cycle power plants are low cost generators due to historically low natural gas prices. The increasing addition of renewable wind and solar power generation further challenge the economic business case for existing NPP operations. Renewables are intermittent producers and introduce dynamics in power generation and minute-by-minute electricity pricing fluctuations that are difficult for NPPs to accommodate. Unlike natural gas plants, NPPs have traditionally been operated as base load (i.e. 100\% power) units, and have not done much load following, i.e., adjust power output based on instantaneous and forecasted grid demand. The wear and tear on the equipment to adopt flexible operations, including loadfollowing, require additional operational costs to maintain the equipment to regulatory standards and are currently not economically feasible in the nuclear power space. Because of the relatively low cost of nuclear fuel and the mandated high staffing levels of an NPP, the cost of nuclear generation of electricity is relatively constant, regardless of the output. Reduced electrical output simply increases the cost of that electricity production in the context of contemporary NPPs. Despite these challenges within the electricity market, NPPs are exploring the opportunity to adopt new hybrid operations concepts to gain cost-competitiveness in other markets. Specifically, the Integrated Energy Systems concepts, such as a coupled electricity-hydrogen production at a NPP will help nuclear utilities become more cost effective. NPPs will be able to produce carbon free electricity during high load demand periods or produce hydrogen for carbon free energy application during low electricity demand periods. 


\subsection{Joint Electricity-Hydrogen Flexible Operations}

The integrated energy system concept focuses on continuing to use NPPs as reliable baseload generators to provide much needed uninterrupted electricity when renewables are not available. However, when renewable production exceeds demand, the plant can redirect its unneeded thermal energy and electricity to other profitable processes like hydrogen production. Producing hydrogen cost efficiently requires modifying the existing plant to support steam extraction for the coupled hydrogen process, termed electricity-hydrogen hybrid operations. Using NPPs in this manner is carbon conscious, because NPPs currently account for roughly $65 \%$ of our carbon free energy, whereas most hydrogen production in North America is derived from natural gas or gasification of coal. Integrating hydrogen production into a NPP is a nontrivial task due to the engineering for the physical systems and their associated instrumentation and controls, human factors engineering required to develop digital displays and procedures to control the process, and then validating and documenting process to meet stringent U.S. Nuclear Regulatory Commission requirements.

\subsection{Steam Extraction Loop}

The designed SEL is connected to the nuclear plant through the main steam header and the condenser (see Figure 1). The SEL receives steam from the main steam header and returns water to the condenser. The system makes use of dual heat exchangers arranged in series. Steam in the SEL undergoes a phase change in the first heat exchanger to produce steam from incoming water in a transport loop and provide superheated steam as an output to the hydrogen process through the thermal dispatch loop (TDL), and ultimately to a hypothetical hydrogen plant. The second heat exchanger ensures the water returning to the condenser is cooled to sub-saturation temperature for the condenser to prevent increasing the back pressure in the condenser. Near the inlet of the SEL, a bypass valve and a flow and pressure control valve are positioned at the inlet of the SEL to regulate the steam entering the SEL and control main steam header pressure. Then the steam travels through three steam traps that dry the steam. A small amount of liquid condensate returns from the steam traps to the condenser. Then, the steam travels through the tube side of heat exchanger SELEHX-1. After the first heat exchanger, SEL-EHX-1, the steam has mostly condensed to a steam water mixture which enters the shell side of SEL-EHX-2 heat exchanger and a level controller maintains water level in the shell side of the heat exchanger. Then the water exits to a drain tank. Finally, there is a level control valve at the end of the loop just prior to the condenser return which ensures that the return is completely liquid to reduce water hammer. The transport loop circulates feedwater to the heat exchangers. The first (EHX-2) acts as a preheat stage and a level controller maintains water flow to maintain shell level in the second (EHX-1) heat exchanger. The end product of the SEL is superheated steam for the TDL that is isolated from the plants main steam system.

Based on the conceptual design, primary information for operators would be flow, temperature and pressure levels at specific sections of the loop as well as data on the parameter differences across specific sections. For example, flow data for heat exchanger inlet and outlet is critical information for diagnostics in the event of a leak within the heat exchanger. Another key parameter for monitoring heat exchanger integrity is radiation. Monitoring radiation of the water on the TDL side of the heat exchangers will confirm tube integrity and that no radiation is being released to the transport loop and thereby outside of the plant in the form of tritium or other isotopes. Again, this is a key indicator to support the diagnostics of a heat exchanger leak. 
The primary parameter for confirming loop integrity would be any difference in flow between the inlet steam flow control valve and the flow control valve at the return to the condenser. This will allow for a top-level perspective on the overall performance of the loop and can direct operator attention to other indicators to begin to find any leaks or other abnormal conditions across the loop. At this point in the design there are not many parameters of interest beyond those discussed above that are specifically linked to a state of operations or task. However as further research and validation is completed there may be modifications to the I\&C environment or operational experience to support any of these tasks.

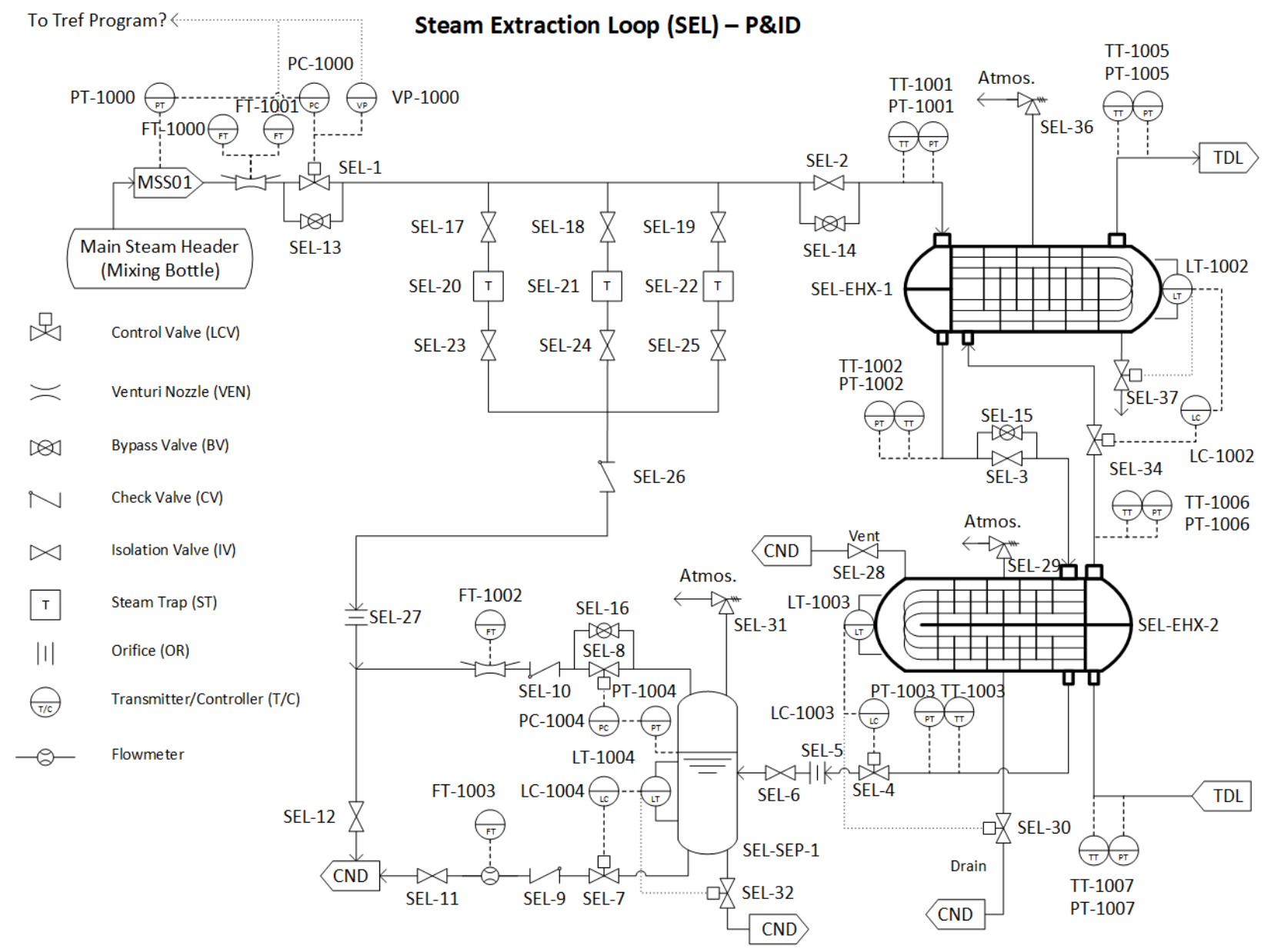

Figure 1. Steam Extraction Loop piping and instrumentation diagram for the current design.

\subsubsection{Steam Extraction Loop Operations}

The NPP and hydrogen production facility will be integrated but controlled separately. Of critical importance from a nuclear power operations and regulatory perspective is that the hydrogen production does not affect the reactivity control of the NPP; the reactivity needs to be controlled by licensed reactor operators. For this reason, operators must control the transition from full power electricity generation to hybrid energy production. The hydrogen plant would place an order for steam, and the nuclear side would carry out the order. The transition to hydrogen production requires first preheating the transport loop and the main steam extraction system. Then the load 
control is set to decrease load at a specified rate. The pressure controller on the steam extraction system would then open to maintain main steam header pressure. As the turbine/generator load decreases, more steam is diverted through the extraction system and ultimately through the transport loop to the hydrogen production system.

Transitioning back to full power generation could be carried out by raising turbine/generator load and having the pressure controller close to compensate. Licensed operators suggested that in the event of the hydrogen plant tripping, the steam could be diverted directly to the condenser. Operationally it wouldn't matter much if the steam is used by hydrogen or not, because it is similar to the steam dumps that already exist. The Generic Pressurized Water Reactor (GPWR) simulator, based on an actual Westinghouse three-loop pressurized water reactor, is designed to dump up to $7 \%$ to the condenser. That magnitude would require initiating a reactivity reduction, and according to operators the baffles in the condenser could be damaged if you dump too much steam directly. Operators reported that GPWR can handle a load rejection event up to $80 \%$ of full power.

There are three primary use cases of operating this system for the design and evaluation steps: warm up/start up, steady state, and shut down. Due to the relative simplicity of the system and design goal, there are only a few key interactions and workflows that are of primary focus from an HFE perspective.

\subsubsection{Warm-up / Start-up}

The key parameters of the warm-up/start up procedure are the temperature of the steam lines and ensuring the proper alignment of valves in the SEL. During warmup smaller bypass valves would be used and reduced steam flow would be directed through the heat exchangers and drain tank to the condenser. Once the system is warmed and pressurized it is ready to receive higher steam flow from the main steam header. The critical parameters are temperature of the steam line at key points, balance of flow and/or pressure between the inlet and outlet flow controllers and valve positions (e.g. open, closed, throttled). As the system further matures there may be additional components or parameters that need to be represented as well. However, the key variables discussed are required to achieve the goal of ensuring the operators can adequately perform and verify warm up and begin dispatching steam to the loop.

\subsubsection{Steady state}

The goal of the steady state operations mode will be monitoring the system and initiating any alarms for off-normal conditions. This section of the workflow will place a high priority on alarms and communication paradigms in order to guide and inform operators in the event of a transient or abnormal operating condition. Due to the relative simplicity of the system, the few operating modes and need for operator actions, there are a limited number of control actions possible for operators to take. In general, the operator will primarily be monitoring systems and state but will not interact much with the system directly while in this state.

\subsubsection{Shut down}

Shutting down the steam extraction loop is another key process to design into the system. The primary concern with this process step will be managing the impact resulting when steam is not sent to the TEDS line. There are some key system engineering concerns involved with the 
disposition of that volume of steam when it is no longer called for. However, from a human-system interface design perspective there is a greater concern in capturing the key parameters and control actions required for the operators to complete the task. It is assumed that there will likely be some minimal proceduralization of some actions and automation of many others.

\section{Human Factors Design Process}

The human factors process to develop the HSI for the electricity-hydrogen hybrid operations SEL is based on NUREG-0711, Human Factors Engineering Program Review Model (O'Hara, Higgins, \& Fleger, 2012). NUREG-0711 was written to provide guidance to the regulator on how to ensure that the engineering process conforms to good human factors principles. It does not actually provide guidance on how to perform the human factors engineering work. The "Guideline for Operational Nuclear Usability Knowledge Elicitation (GONUKE; Boring, Ulrich, Joe, \& Lew, 2015; Boring, Lew, \& Ulrich, 2016) provides additional detailed guidance on how to perform the human factors activities.

The guidance follows a typical human factors process. The specific activities for nuclear process control applications are comprised of the following steps:

1. Obtain background and engineering documents to develop understanding of system functions

2. Perform a functional requirements analysis mapping items from step 1 to required human functions and tasks

a. Identify all required components, sensors, and controls that need to be represented in HSI

b. Organize the components into functional groups

3. Determine a general layout and the number of displays required to represent the functional groups

4. For computer displays, determine a navigation scheme that assures a maximum of two clicks (operator actions) to access any given display

5. Determine the iconography for each HSI item type

6. Iteratively develop static mock-ups

7. Perform design verification;

a. NUREG-0700

b. ISO-11064 ("Ergonomic Design of Control Centres")

c. EPRI-3002004310 ("Human Factors Guidance for Control Room and Digital Human-System Interface Design and Modification")

d. Expert evaluations with operators

e. Revise static designs to conform to standards and expert evaluations

f. Document human factors issues and dispositions

8. Perform design validation:

a. Implement dynamic prototype in simulator

b. Develop scenarios and procedures

c. Identify performance measures

d. Perform operator-in-the-loop testing 
These steps map approximately to three of the four phases of NUREG-0711 as shown in Figure 2. Steps 1-2 are Planning and Analysis, Steps 3-6 are Design, Steps 7-8 are verification and validation. The execution of each step for developing the HSI for the electricity-hydrogen hybrid operations SEL are elaborated in the following sections.

The work presented here pertains to the steps of the process up through step seven, which spans the bulk of the design activities for building novel displays for complex nuclear process control applications. The remaining step pertains to validation testing of the interface to ensure that it can be used to successfully complete operator tasks. The overall project is ongoing and future work is scheduled to perform the evaluation of the designs described in this paper.

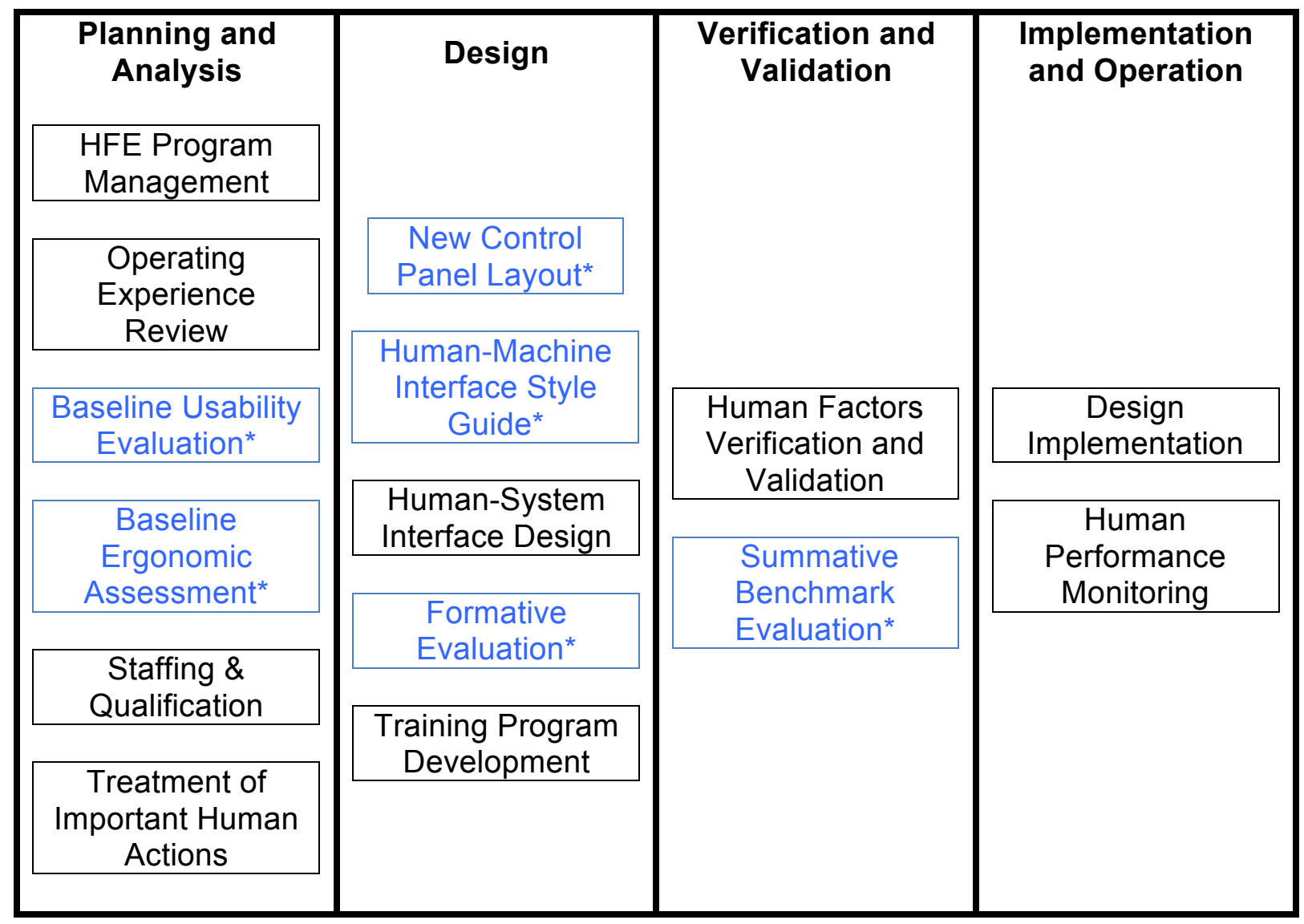

Figure 2. NUREG-0711 activities organized by four phases. The items in blue are additions provided by GONUKE.

\subsection{Step 1-Obtain Background and Engineering Documents}

At the onset of the project an initial meeting was held to coordinate the team and disseminate the existing knowledge of the proposed system. The system itself had not been designed yet; therefore, all activities including the human factors activities occurred in parallel. Early engagement with human factors is critical for a successful design and helped inform the system design itself.

The human factors team arranged for structured operator interviews with the goal of eliciting the operational knowledge concerning how best to design the SEL to enable the simplest 
operations and reduce any impact these would have on the existing operations of the plant. The particular operators interviewed possess unique detailed knowledge of the generic pressurized water reactor (gPWR) and this information was used to modify the SEL. The operators' knowledge proved invaluable to both an understanding of the operational requirements and constraints needed for the SEL. At the close of the interviews an initial system design was formulated. The system engineers then provided the resulting piping and instrumentation diagram (P\&ID) to the human factors team to enable the start of the HFE design. Armed with this background and documentation, the team proceeded to the next step in the human factors process, which is the functional requirements analysis.

\subsection{Step 2 - Functional Requirements Analysis}

This section describes how to identify the required components, sensors, and controls for the HSI through systematic processes using the background information and documents obtained from Step 1. NUREG-0711 describes twelve elements of an HFE program. The operating experience review activity suggests performing the following three elements: 1) functional requirements analysis (FRA), 2) function allocation (FA), and 3) task analysis (TA). Descriptions of the three elements are provided below.

The FRA is a method to identify functions that must be performed to satisfy the system's overall goals. It defines the high-level functions that must be accomplished to meet the system's goals and desired performance as well as delineate the relationships between high-level functions and the system's goals. Figure 3 shows an example of FRA for NPPs. In the figure, the goal of ensuring safety is decomposed into functions, processes, systems, and components.

The FA refers to assigning the functions to personnel and automation such as manual control (i.e., no automation) or automated systems (i.e., fully automatic control). The results of FA is important information to design an interface, because some components in the interface could be additionally necessitated or un-necessitated according to the automation level. For example, some of the automatic systems additionally require an action that initiates a system to achieve the required function. In this study, as a reference to perform FA, NUREG/CR-3331 (Puliam et al., 1983) has been considered. It defines the level of automations to be assigned to a function as well as suggests detailed requirements of the function to be available with several questions. The following sentences describe the five levels of automation defined in NUREG/CR-3331 (Puliam et al., 1983):

- Automatic (Auto): completely automatic, without a means for manual action

- Automatic-AND-Manual (AAM): a configuration that can be provided both manually and automatically. The operator has the capability to provide manual actuation at any time but does not have the capability to defeat the automatic actuation.

- Automatic-OR-Manual (AOM): a configuration that can be provided both manually and automatically. The operator has the capability to select the mode of actuation, which can defeat automatic actuation.

- Automatic-XOR-Manual (AXM): A configuration that can be provided both manually and automatically. There are sharing of actuation responsibilities between the human and machine components.

- Manual: a fully manual configuration without a means for automatic actuation. 
TA is a method for analyzing specific tasks that personnel perform to accomplish their functions. In this analysis, it is identified that specific elements like alarm, information, control, and task support are needed to perform the tasks.

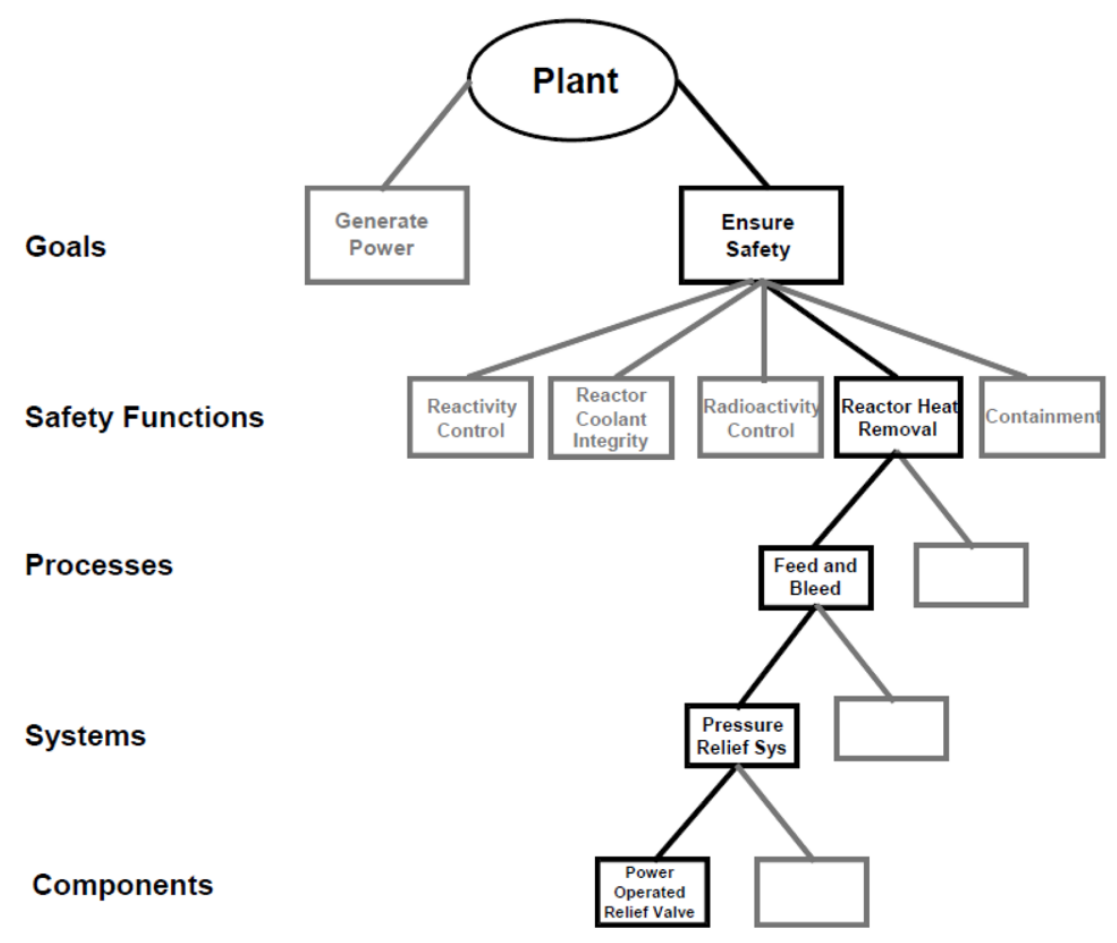

Figure 3. An example of FRA for NPPs

The three elements in the HFE program systemically identify all the components required for plant personnel to perform tasks as well as give an idea as to how to design a human-system interface. As introduced above, the SEL is a relatively new system, therefore, how to design the interface for the SEL has not been studied yet. In the following subsections, three parts are related to the goal of this study: 1) assumption for an operation concept, 2) FRA, FA and TA focusing on the SEL, and 3) a list of components and their design in HSI, will be explained.

1) Assumption for an operation concept

To perform FRA, FA and TA for the IES, some information in terms of operation needs to be assumed. Following are the assumptions based on the system and its characteristics.

- To produce hydrogen in the IES, thermal energy from high temperature steam and electrical energy for breaking $\mathrm{H}_{2} \mathrm{O}$ into $\mathrm{H}$ and $\mathrm{O}$ are required.

- The high temperature steam is supplied from a steam generator, while the electrical energy comes from the non-class $1 \mathrm{E}$ main generator.

- In other words, the hydrogen production is possible when the plant reaches a steady state conditions at the required power level.

- A process for start-up/shut-down for IES is required

- The SEL follows a start-up/shut-down process with the secondary system. 
- The SEL will require 5\% of the NPP full power steam flow at full power steady state.

- Full-power steady state with IES

- The SEL accounts for 5\% additional thermal load in the full power steady state.

- The steam generation in SEL makes adequate pressure to circulate high temperature steam.

- Abnormal operation with IES

- If the cause of abnormal operation is not from IES, it may keep operating or be disconnected depending on an operator's decision.

- If the cause of abnormal operation happens at IES, some of functions are required to ensure the safety. The following are a couple of abnormal situations that could occur.

$\checkmark \quad$ Extraction loop steam leak before heat exchanger

$\checkmark$ Heat exchanger tube leak: contamination of the secondary coolant (secondary coolant chemistry issue), leaking the secondary coolant into the transfer loop for the hydrogen system (radiation contamination)

$\checkmark \quad$ Transmitter failure

- Emergency operation with IES

- The SEL should be isolated in any emergency situation; furthermore, the SEL should not be responsible for the mitigation of the event.

2) FRA, FA and TA focused on the SEL

Appendix A shows the results of the FRA and the FA. For the FRA results there are two defined goals: producing hydrogen and ensuring safety. Producing hydrogen consists of five functions, 1) TDL water supply, 2) TDL water control system, 3) steam flow control in IES, 4) steam pressure control in IES and 5) steam condensation system, while the goal of ensuring safety has only one function: system isolation. For each function, Appendix A includes details such as success path, controlled component and controlled parameter. For the results of the FA, each success path has been evaluated by the criteria suggested in NUREG/CR-3331 (Puliam et al., 1983).

Appendix B shows the results of the TA. For the TA, this study considers one of the methods for performing task analysis, i.e., decomposition method (Annett, 2003). This method suggests a structured way of expanding the information from a task description into a series of more detailed statements about particular issues. The process also systemically gathers further information about specific aspects of the task or the facility. In the Appendix B table, each task is divided into subtasks and the detailed information such as task verb, task device, its characteristic, influential parameter is developed for them.

3) List of components and their design in HSI

Appendix $\mathrm{C}$ shows a list of HSI components identified from the results of the FRA, FA and TA. It includes the components required for operators to perform tasks, the design types and the recommended shapes that could be displayed in the HSI. 
Some of the task devices are combined as a HSI component because those are already modeled in another interface, therefore, it is not necessary to consider the task device separately in the SEL interface. For example, the booster pump, TDL water pump and TDL water heater that needed to supply TDL-water could be shown as a signal in the SEL interface because these are already shown in an interface for the TDL secondary system. Now that the information has been identified through the FRA, FA, and TA, the next steps in the process is to design the actual interface to represent these elements in an effective and usable manner.

\subsection{Step 3 - Determine the General Display Layout}

Due to redundancy considerations, the envisioned HSI will be housed on two separate displays using separate thin clients to ensure that even if one were to fail, a backup would be available to enable continued operation. This same scheme was adopted in control room modernization upgrades for digital turbine control systems in a number of previous collaborations and proved effective. In addition to redundancy, the multiple monitors can be used by the operators during normal operations, and therefore the effective functionality of the displays is doubled. For the SEL, this enables the indication display to be viewed simultaneously with the control display, and this helped shape the overall layout scheme for the system. Though normal operations can be performed in this manner, it is still important to demonstrate the operability of the system with only a single display during the validation portion of the human factors process concerned with examining the usability of the system through operator testing.

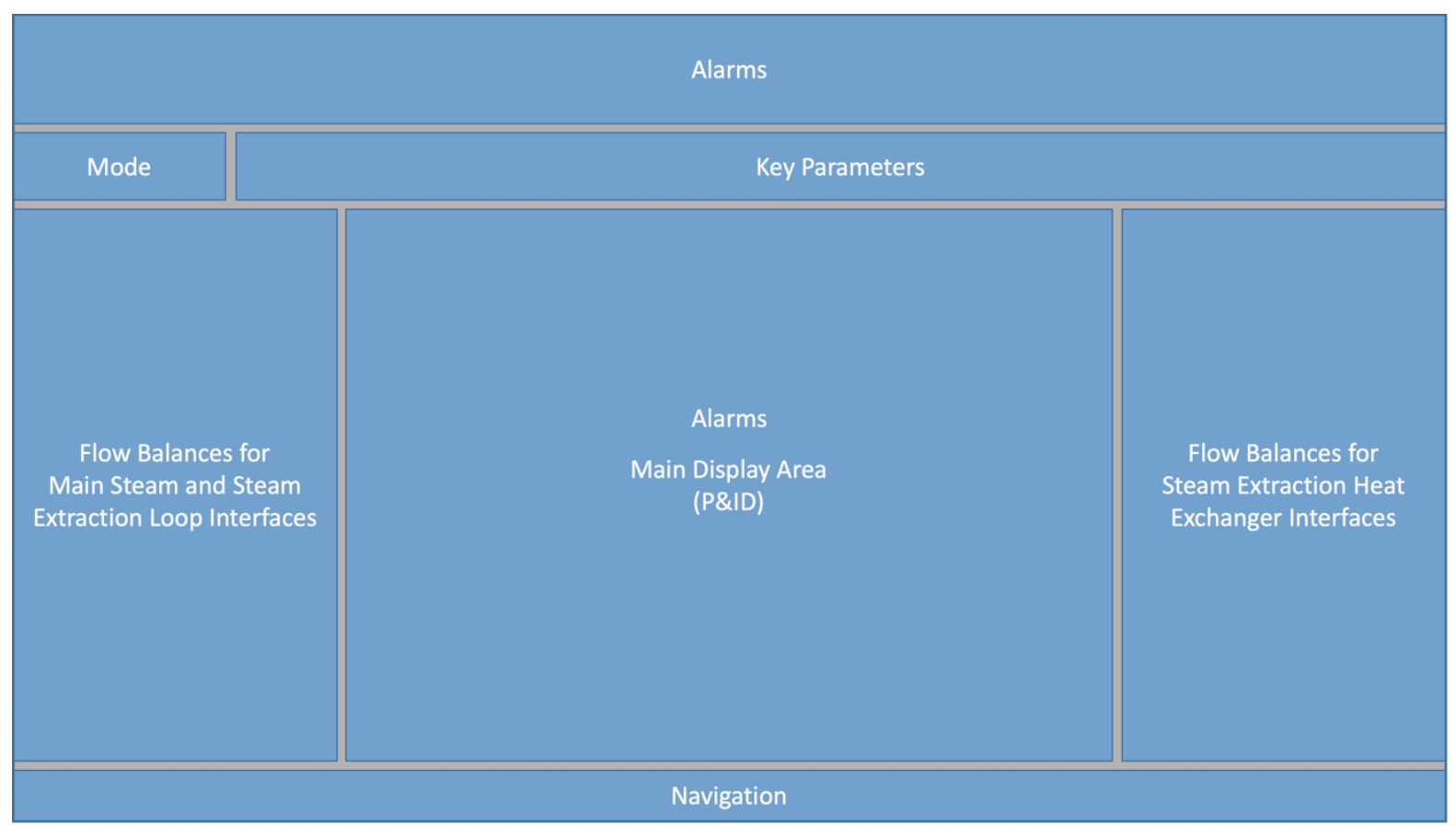

Figure 4. Display Layout for indication displays used for the steam extraction loop. 
The layout of the indication display for the SEL (see Figure 4) follows the general scheme found in existing analog nuclear control rooms in which the alarms are presented along the top, key parameters are directly below the alarms, and the bulk of the detailed information for the display resides in the middle. A section along the bottom supports buttons for navigation and special alerts that allow the operator to directly navigate to the page with the associated alert.

\subsection{Step 4 - Navigation Scheme}

The complexity of systems in nuclear process control requires the use of a multi-windowed display in which the operators must navigate to the appropriate display in order to obtain information or control a component in the desired system. NUREG-0700 (U.S. Nuclear Regulatory Commission, 2019) states that any display should be accessible within two-clicks to ensure speed of navigation. As such, it is important to consider the number of screens and organize these appropriately to ensure the operator can quickly access them. Fortunately, the SEL is a quite simple simple, in relative terms to other nuclear systems, and therefore little navigation is required. Since the system design is still under active development, it is important to ensure that any additional screens can be quickly navigated to.

\subsection{Step 5 - Iconography and Style HSI Elements}

A crucial aspect to ensuring a good design involves identifying a design specification that outlines the styles and requirements for each of the components within the display. The human factors research team has extensive experience performing control room modernization to digital upgrades and was able to draw upon a large body of prior work to arrive at a cohesive style for the SEL HSI.

\subsubsection{Prior Work Design Concepts}

Since the GPWR simulator is the platform for the SEL concept demonstration, the authors looked to some of their previous designs for concepts that have proven effective in prior applications. A brief description of prior work illustrates design concepts that were informative for the style adopted for the electricity-hydrogen hybrid operations for the SEL HSI design. Examples from previous design efforts and their specific concepts that were considered for this SEL HSI are described in the following sections.

\subsubsection{Digital Turbine Control System Upgrade}

The human factors research team has experience working with utilities undergoing turbine control system upgrades. Many utilities have pursued turbine control system (TCS) upgrades because of the tangible benefits in the form of extra megawatt capacity that can be achieved. Furthermore, the TCS is not considered a safety related system, and therefore the regulatory risk of performing the upgrade is minimal for the utility. As a part of the TCS upgrade one partnering utility pursued a standardized HSI approach in which the TCSs across all units in the fleet would have the same HSI style. The utility's ultimate end goal was to extend the style and specifications of the digital TCSs to other systems as those are replaced by digital upgrades in the future. Several design concepts were considered and carried over to the SEL HSI. As can be seen in Figure 5, the layout of the display is advantageous for representing a P\&ID of the system and related 
information nearby. Furthermore, the concept of the prominent parameters arranged in a ribbon across the top of the display is also a useful design concept for the SEL. The displays and design concepts developed for the digital TCS underwent extensive standards reviews and therefore provide styles, such as the red and green valve position color scheme, that adhere to established nuclear standards and can easily be adopted for the SEL HSI design.

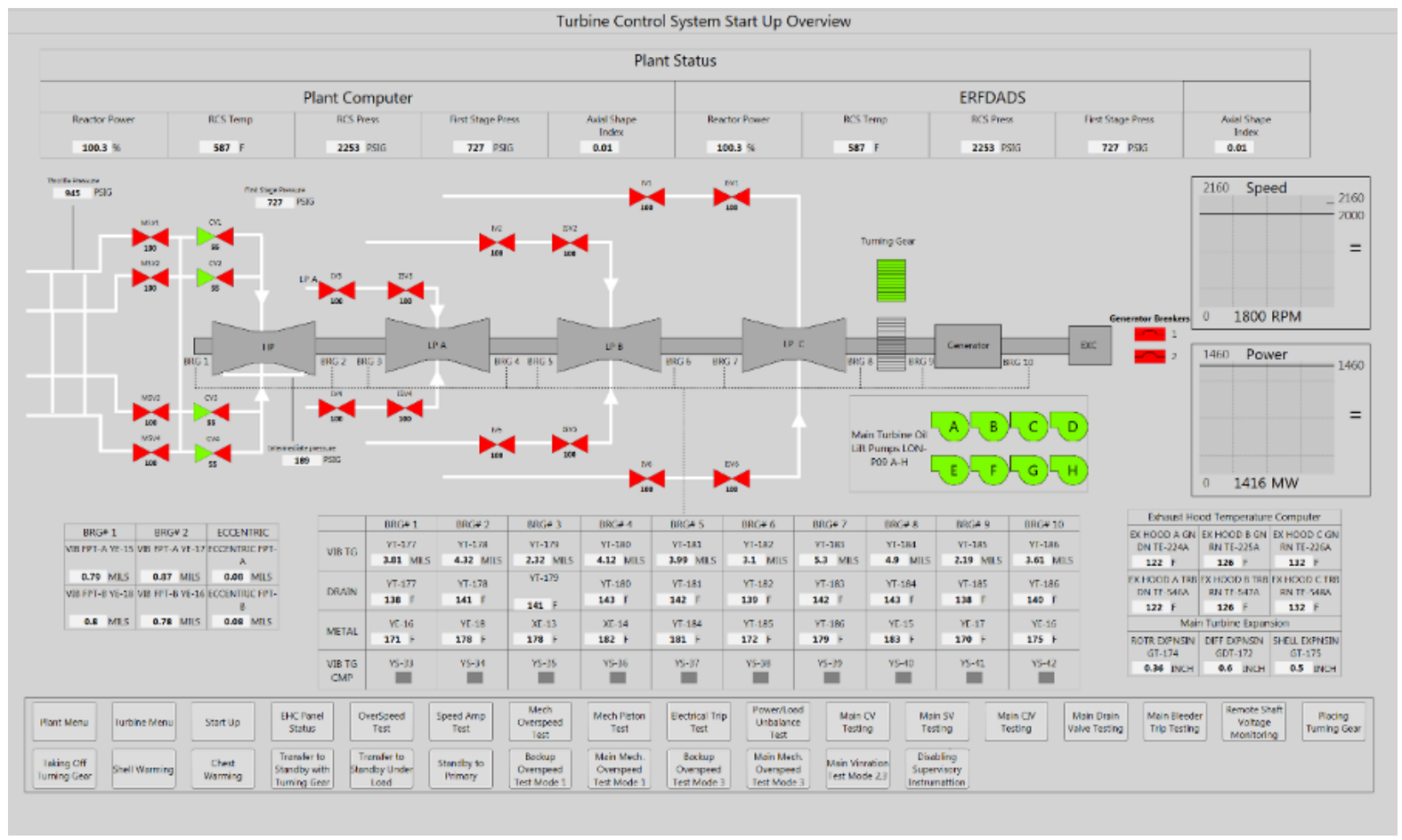

Figure 5. Turbine Control System Overview Display

\subsubsection{Computerized Operator Support System}

The Computer Operator Support System (COSS; Ulrich et al., 2014; Lew et al., 2014; Boring et al., 2015; see Figure 6) is an advanced digital HSI created to examine the concept of an integrated control system without the constraints that current control room modernizations face. As such, the concepts are more forward thinking and were intended to inform the nuclear industry as to possible technological solutions that could be adopted in the future for nuclear process control applications. The COSS is a collection of a number of technologies that are outside the scope of this document; however, the most prominent feature of the COSS is the underlying prognostic system that is able to detect anomalies and present those within the familiar P\&ID display that operators were comfortable interacting with from their current analog operations. The prognostic system, PRO-AID, was developed by Argonne National Laboratory and through a joint project it was linked to the HSSL at INL to run remotely and support operator crew evaluations. PRO-AID affords the capability to determine system faults, such as leaks and blockages, by leveraging the existing sensor data at a plant. Accuracy of the diagnosis depends upon the richness of data provided by available instruments and PRO-AID was designed such that it only requires the user to define the system at the P\&ID level. From there, the PRO-AID algorithm is trained from steadystate data so it can recognize abnormalities during steady state operations. Fault detections are then conveyed to operators through the HSI screens with distinctive yellow-green color alerts. 
The prognostic feature of COSS is not as of yet needed for the SEL system, but many of the design features proposed in COSS were reviewed and adapted for the SEL HSI designs. Specifically, the SEL designs inherited several COSS designs concepts including the dullscreen approach, trend displays, and valve representations.

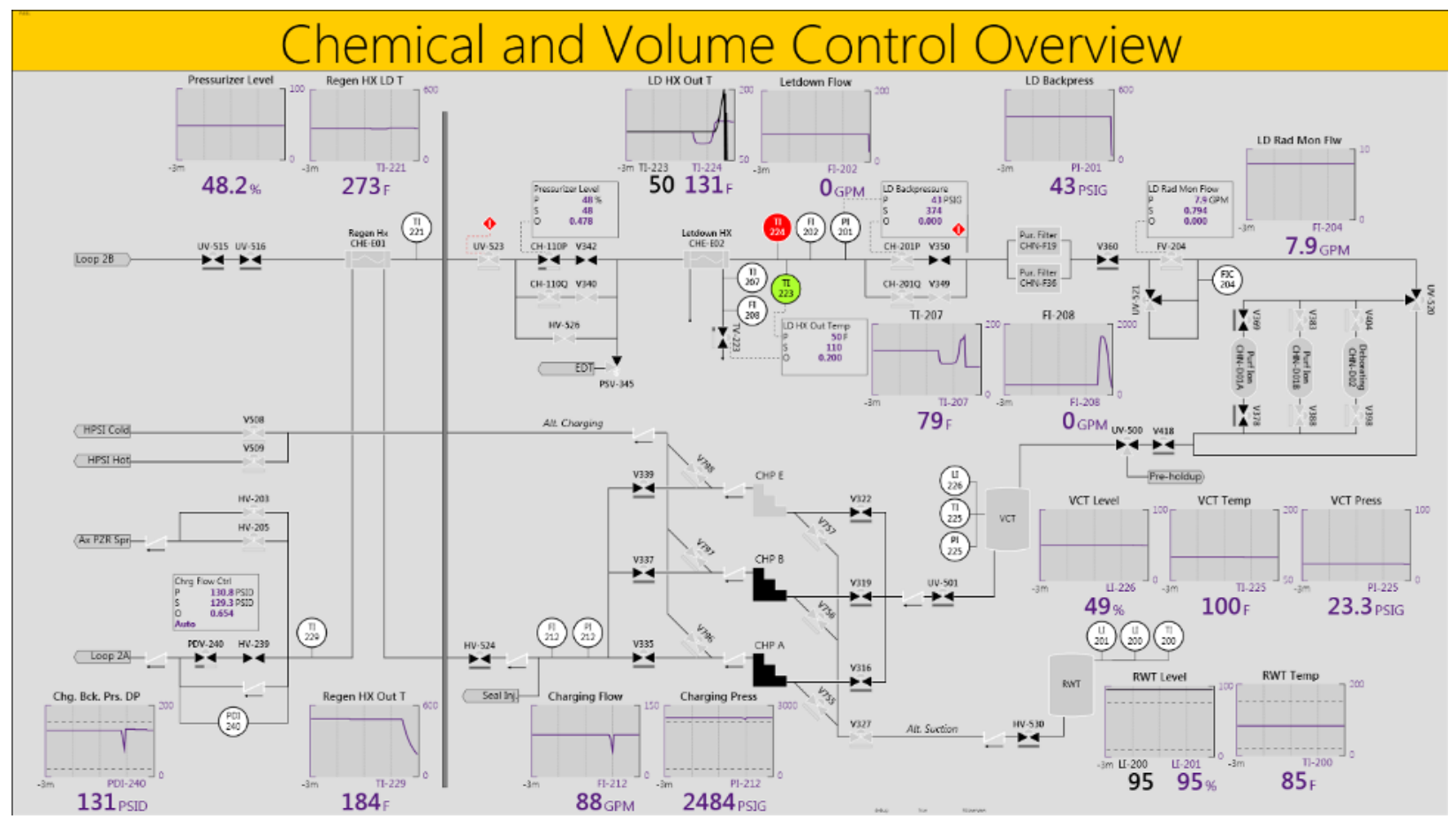

Figure 6. Computerized Operator Support System Overview display

\section{Dullscreen Approach}

The COSS adheres to a dullscreen approach in which the display background is grey and components within the display are various shades of grey to limit contrast (Ulrich et al., 2014). This is done so that color can be reserved for key information and creates a "pop-out" effect which is highly salient and easily detectable by the display viewer. This is a basic design concept that is subtle yet creates usable displays that highlight key information. For example, in Figure 6 the charging pumps are black to denote energized and grey to denote de-energized, while the sensor value that is off normal is highlighted in red and is highly visible. In this particular example, the charging pumps provide little actionable information, but the alarmed state of the indication is valuable and highly salient so that the operator detects it quickly to begin diagnostics as to the cause of the alarm.

\section{Trend Displays}

The trend displays are quite useful for clearly depicting rates of change and historical context for the instantaneous value for a parameter. Trend displays use the chart area to provide the range of the value and give context as to whether the correct operating band has been achieved for a parameter. 


\section{Valves}

Initially, COSS valves were black and white but since operators expressed a preference for the $\mathrm{red} / \mathrm{green}$ design discussed earlier, the red/ green design from the TCS design was adopted. The bar chart indication for the valve position, which was used in both the TCS and the COSS design, is useful for operators to quickly determine a valve position. The operator does not need to read a digital numerical value to identify the position but can quickly identify the valve position at a glance.

\subsubsection{Additional Design Concepts Considered for the Steam Extraction Loop HSI}

In addition to reviewing design concepts from prior work, some initial design work focused on reviewing and identifying indications and operator communication principles for automated control schemes. Figure 77 displays some initial design concepts for the envisioned HSI and shows a focus on indicators to report key parameters rather than a large number of control items arranged in a traditional piping and instrumentation diagram (P\&ID). The initial HSI design concepts assume a fully digital display and control scheme (Boring et al., 2017). The HSI is intended to serve as a serve as a standalone digital display within an existing analog control room but could also be integrated within any existing digital HSIs, such as could be the case in some plants that have adopted digital turbine control systems (Al Rahsdan et al., 2017). The initial design parameters are based on the information from Appendix C.

In Figure 7, the number 1 shows the trend-style recorders and graph indicators. The values update in real-time with a band for expected range and dual axes to show two variables simultaneously. The dual axes functionality is specifically useful if the two variables being displayed have an inherent relationship such that a value of one impacts a value in another. For the initial design, dual axes are used for flow and pressure since they are typically related in power plant systems. However, at this stage of the SEL design it is not known what that relationship is and if the dual axes chart would be of value.

The area marked with a number 2 displays two specific items; first, the alarms list and second, the parent system status. efficient to integrate it into an existing alarm list in the control room. It is simpler and of more value to the operator to include this information on the SEL display screen as shown. The parent system status "stop lights" are designed to show the operator a "go/no-go" style indicator for the systems that the loop is functionally dependent on and their status. This is to prevent the possibility that an operator performing tasks related to the thermal dispatch may be impacted by a transient related to a turbine, condenser, or any other systems identified to have some form of connection with the thermal dispatch loop.

The area marked with a number 3 exhibits the automated control scheme that was in the initial design. As stated in the concept of operation sections, there are several key parameters that are of interest in the performance of system operations; however, due to the simplicity of the system the FA/TA processes concluded that there was little need for manual control intervention at such a granular level and it would enhance system efficiency and performance to make use of automation to take the control actions and have the operator perform supervisory command and control functions. The stoplights from parent system states are present here as well to show when a step 
has been performed satisfactorily and the trend to the right will change based upon the current action being undertaken.

The area marked with a number 4 shows a potential design concept for a fixed region of the SEL display for the actuation of emergency control steps. The primary concerns identified from the FRA include the need for a rapid shutdown, which may require the need to perform a steam dump to the main condenser instead of dispatching steam to the SEL in the event of a load rejection by the grid or attached plant. These were placeholders only and there was not any discussion or further design of these workflows. It is valuable to mention that it is likely that an emergency situation may necessitate a full operator interface shift to specific controls or indicators related to parameters of interest for the event.

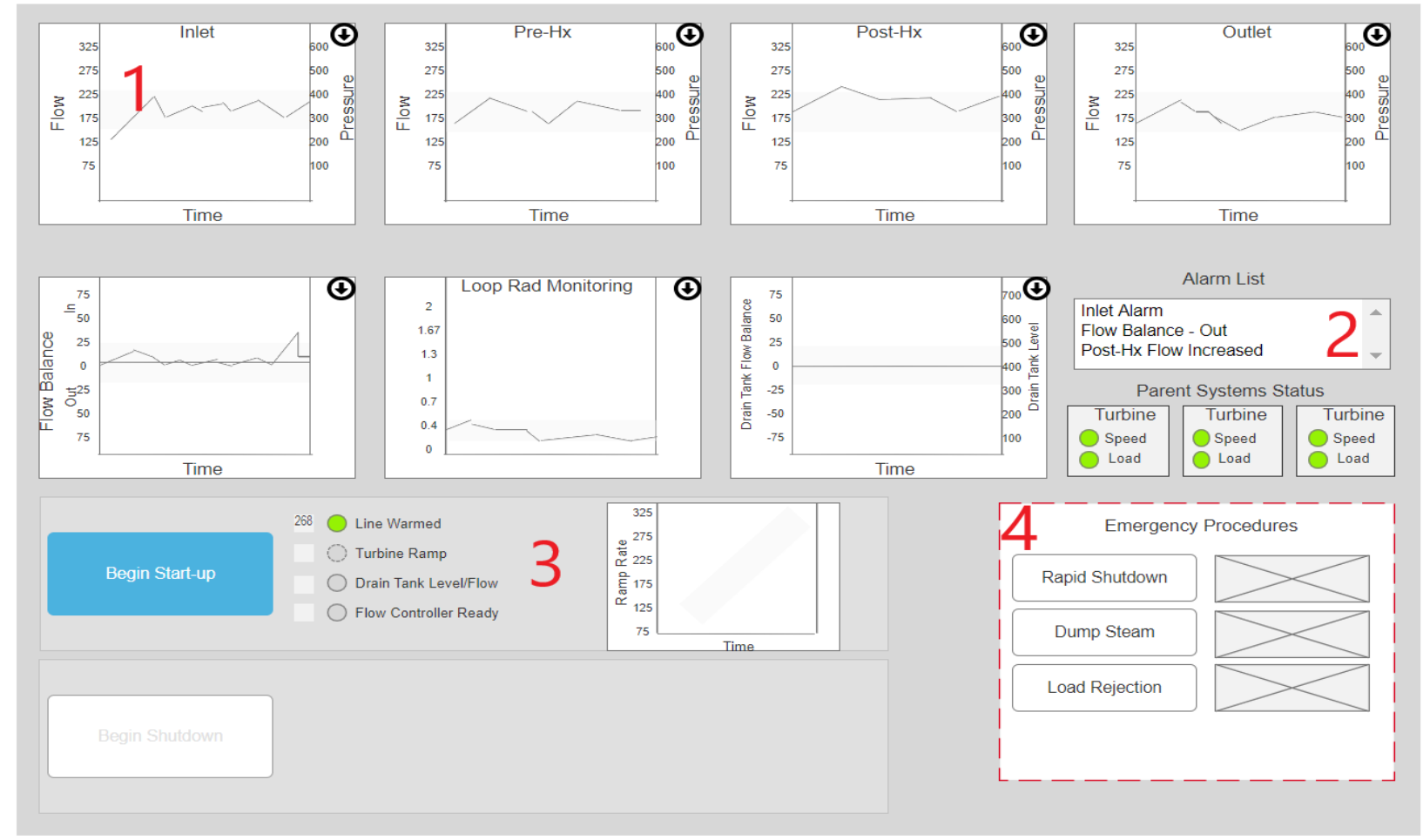

\section{Figure 7. Proposed steam extraction loop Interface design concepts.}

Ultimately, only a sub-portion of the original design concepts in Figure 7 were included in the final design of the SEL. The abstract nature of the interface formed by the collection of trending variables was ultimately replaced with a piping and instrumentation diagram format based on preferences obtained from the operators during their reviews of the design concepts. The general concept for displaying the system state while performing evolutions, denoted in region 3 in Figure 7 was included in the final design for the control display of the HSI.

\subsection{Step 6 - Iterative Prototype Development}

As stated above, after conducting an FRA and FAA, a preliminary HSI was designed for the SEL (see Figure 8). The design was intended to be retrofitted into the hybrid (analog and digital) control room GPWR installed in the HSSL to allow for usability and formative validation exercises to be conducted at a future date. The interface design builds on general design findings from 
previous efforts designing the COSS for NPPs. The layout is comprised of two monitors. As previously noted, each monitor would be connected to separate thin clients on separate power buses and network buses to provide redundancy from hardware failures and onsite power failures. One monitor would be used to display an overview of the extraction system and the second monitor would be used for digital controls with which the operator would interact.

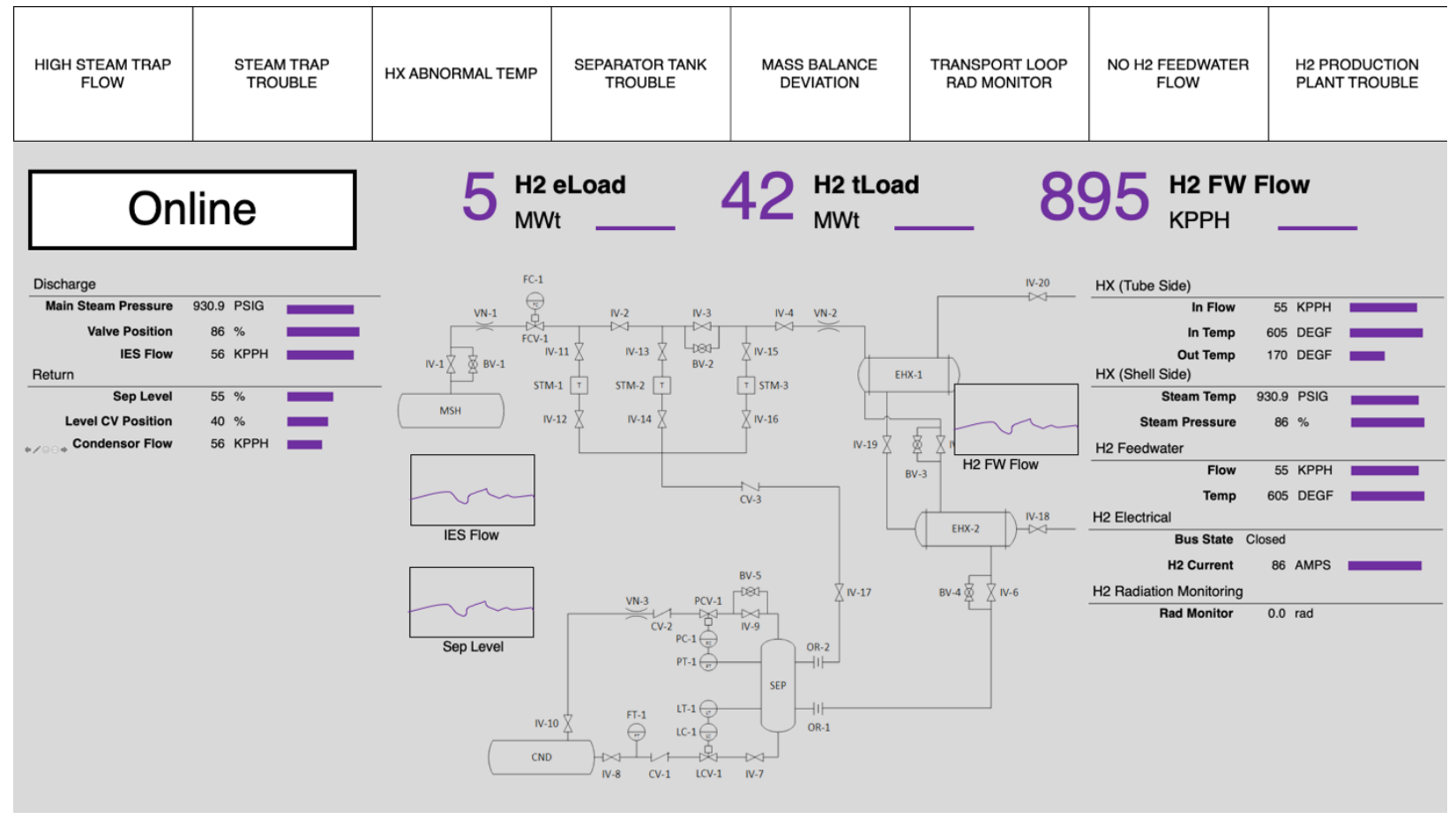

Figure 8. Initial steam extraction loop indication display.

The overview screen has a row of alarm tiles across the top of the display. Below the alarm tiles is a row of primary system indicators that would lend themselves to checking system state "at a glance." These primary indicators are large and intended to be legible from across the control room. In the center of the display is a P\&ID representation of the SEL and TDL. The HSI displays the engineering P\&ID drawing, but a simplified P\&ID would be created for the interface that would eliminate manual components such as manual isolation valves that would not have sensing instrumentation. On the right trend displays were included for the heat exchanger to provide context for the relative state of the heat exchanger at any particular moment. Along the ribbon for the prominent parameters is a different type of trend display called a sparkline. Sparklines lack the contextual information such as the range of the parameter formed by the background of the chart area, but they are quite effective for providing context for rate changes in variables the sparkline is quite effective and therefore it is quite useful for at a glance context for a given parameters. The primary purpose of the P\&ID is to display valve alignments so that operators are aware of extraction flow. The valve alignments and flows would change depending on whether the system is shutdown, warm-up or steady state. To the left and right of the P\&ID are pressure, temperature, and flow indicators arranged in tables categorized by sub-systems (loops) in the extraction system.

The control system for the extraction loop (see Figure 9) aims to minimize the operational complexity of the system, minimize the number of controls and indications needed for operators, and maximize automation. However, the system would be operated independently of other reactor and turbine/generator controls. The operations of the extraction system would require procedures 
to coordinate dropping turbine load and monitoring reactivity while simultaneously increasing extracted steam. Likewise, shutting down the extraction and handling abnormal situations would require procedures. With these considerations in mind, the resulting control display is simplified to two buttons for warming and starting load following - a button to trip the extraction system and some additional controls for manually operating the two controllers in the system, isolating various components of the system, and managing the breaker for electricity to the hydrogen production.

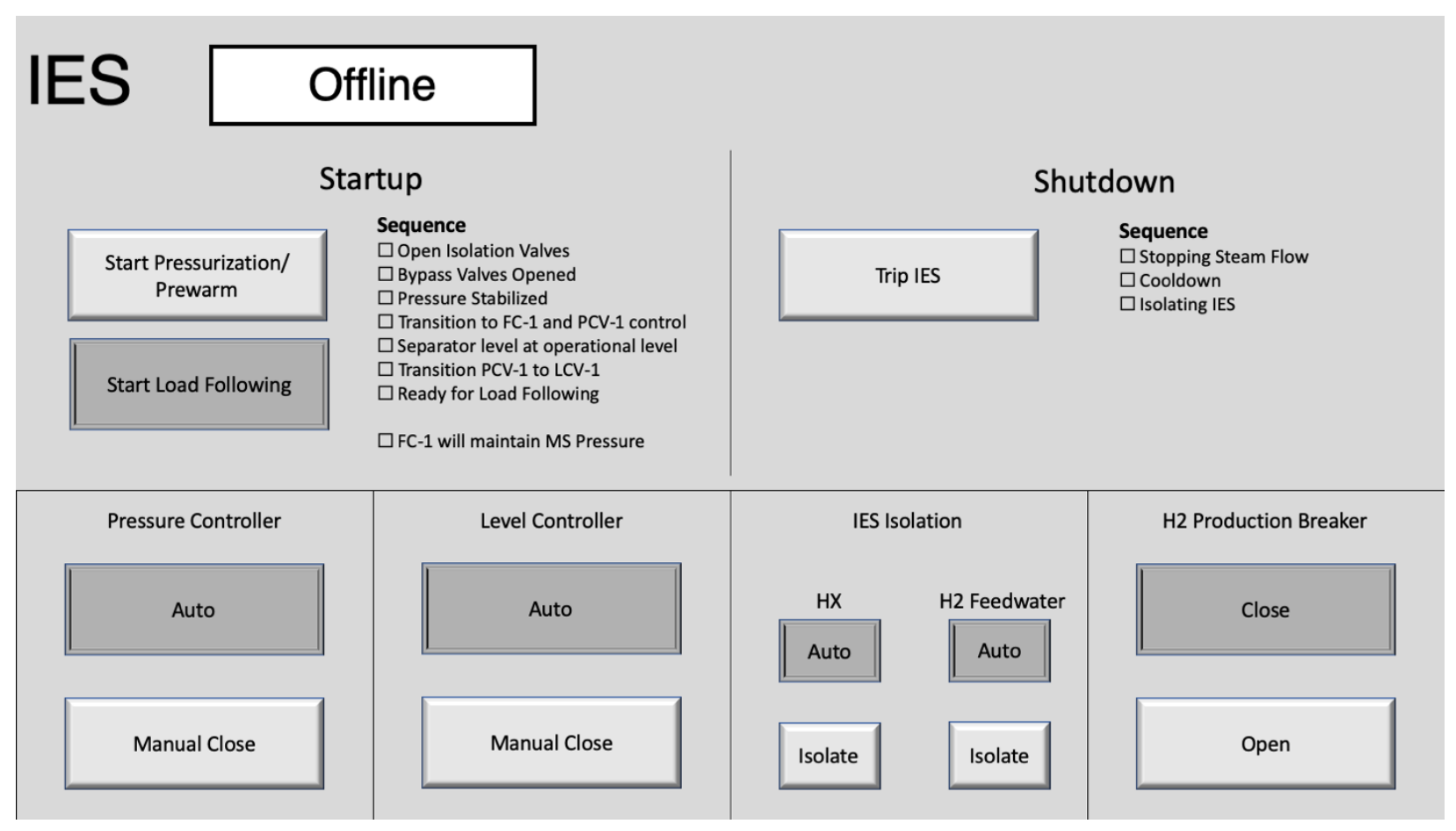

Figure 9. Initial steam extraction loop control display

\subsection{Step 7 - Design Verification}

\subsubsection{Expert Review}

NUREG-0700 rev 3, Human Interface Design Review Guidelines, provides a comprehensive and detailed set of standards addressing human factors principles to assist the regulator in evaluating interfaces for nuclear power plants (Nuclear Regulatory Commission, 2019). NUREG0700 contains thousands of guidelines arranged under 13 broad topics as can be seen in

Table 2. The team decided to use revision 3 since the standards are more relevant and informative to digital design. Since NUREG-0700 is comprehensive for a wide variety of HSI issues, only a subset of the guidelines are applicable to the SEL his. As a result, one human factors team member reviewed the different sections to determine their applicability to this particular system. The resulting analysis yield a total of 256 guidelines deemed relevant for the SEL HSI.

An aspect of NUREG-0700 rev 3 that was potentially applicable to the evaluation was the prevalence of guidelines related to interactions within the system. Entire sections for alarms, error messages, error recovery, navigation, and general user actions within the system were developed to a significant degree relative to rev 2 . This is understandable since rev 2 of NUREG-0700 was 
released before digital designs were possible for nuclear plants. However, for the current state of the SEL HSI interface there were very few dynamic elements constructed, therefore many of the new standards were not used. For this project the two reviewers evaluated general principles of clarify, organization, color, salience, and navigation as well as the more static guidelines in NUREG-0700. This approach will identify any issues in the basic components and style of the interface. The expanded evaluation process will be completed at a later date and cover the interactions and dynamic elements once they are developed and implemented. The tables depicting the static and dynamic guidelines are shown in Tables 1 and 2.

Table 1. NUREG-0700, Revision 3, static design guidelines arranged by section.

\begin{tabular}{|l|l|}
\hline \multicolumn{1}{|c|}{ Section } & \multicolumn{1}{c|}{ Subsection } \\
\hline Information Display & 1.1. General Display Guidelines \\
\cline { 2 - 2 } & 1.2. Display Formats \\
\cline { 2 - 2 } & 1.3. Display Elements \\
\hline User-Interface Interaction Management & 1.4. General User Input Guidelines \\
\hline Soft Control System & 7.1-7.2 General \\
\cline { 2 - 2 } & 7.3 Information Display \\
\cline { 2 - 2 } & 7.4 User-System Interaction \\
\hline
\end{tabular}

Table 2. NUREG-0700, Revision 3, dynamic design guidelines arranged by section.

\begin{tabular}{|l|l|}
\hline \multicolumn{1}{|c|}{ Section } & \multicolumn{1}{c|}{ Subsection } \\
\hline $\begin{array}{l}\text { User-Interface Interaction } \\
\text { Management }\end{array}$ & 2.2 User Input Formats \\
\cline { 2 - 2 } & 2.5. Managing Displays \\
\cline { 2 - 2 } Alarm System & 2.7 User Assistance \\
& 4.1 Alarm Definition and Treatment \\
\cline { 2 - 2 } & 4.2 Information Display \\
\cline { 2 - 2 } & $\begin{array}{l}\text { 4.3 User-System Interaction and Controls } \\
\text { 4.4 Reliability, Test, Maintenance, and Failure Indication }\end{array}$ \\
\hline
\end{tabular}

There were other sections within the NUREG that were not evaluated for this system at this time: Analog Display and Control Devices, Safety Parameter Display System, Group-View Display System, Computer-Based Procedure System, Automation System, Communication System, Workstation Design, Maintainability of Digital Systems, and Degraded HSI and I\&C Conditions. The rationale for their exclusion is primarily that they are inapplicable to the proposed 
solution, e.g. analog control devices are not applicable to a fully digital system. Another potential reasoning is that the system is not nearing a level of implementation that would necessitate the inclusion of those specific guideline sections, e.g. workstation design. These areas may be the focus of future evaluations of the system.

Two human factors team members performed the review. The results of the analysis are summarized below. The interface version used for this review was both the supervisory and control screens from Section 2.6. A critical aspect of the design on this project can be described as "less is more." This was partially influenced by the relative simplicity of the system, which enabled us to eschew the dozens of indicators generally needed in the more complex nuclear systems, and partially impacted by the team's desire to begin to focus on what the operators need within the context of automation and digital modularity. As more modern reactor control systems are developed, there is a need to rethink the sheer quantity and complexity of legacy reactor I\&C postures and make a concerted effort to minimize and simplify. This design verification was incredibly useful to highlight some of the areas where we minimized too much and gave the team solid design recommendations for future iterations.

Table 3, below, shows an example section from one reviewer's NUREG-0700 evaluation. The compliance assessment and comments on these guidelines were similar across both reviews. Specifically, as the design attempted to be as minimal as possible, there were some reference characteristics and elements necessary for relative judgments, such as a means to identify normal operating ranges and allowing operators to identify if a variable is approaching a critical level.

Recommendation 1 - Identify a low cognitive workload means of enabling relative evaluations (ranges, critical marks, relative state identifications).

It was noted by one reviewer that the P\&ID shown was of an older system design instance. This brought up the need to have the final design in place, but also brought up questions as to how the interface would enable the P\&ID to be dynamic. Simply inserting an image of the system P\&ID into the center of the interface doesn't use the realities of digital design to its full potential. Therefore, there were two recommendations to the design and development teams.

Recommendation 2 - Due to the changing system design of this hypothetical system the interface should have a simple way to change out the P\&ID.

Recommendation 3 - Develop a more 'alive' P\&ID that can be used in the supervisory and diagnostic functions of the system.

The evaluation also caught several inconsistencies related to the font size and relative size of various elements. This was expected that there would be some differing characteristics as the designers were working in a variety of prototyping tools prior to the assembly of the interface. The design team will be assigning specific values for these components in order to assist in standardizing all components for future iterations.

Recommendation 4 - Implement a 'style guide' or other governing document that defines the font size, spacing, sizing, etc., of all components. 
Table 3. Example results of the NUREG-0700 guideline review of the SEL HSI

\begin{tabular}{|c|c|c|c|c|}
\hline \begin{tabular}{|c|} 
NUREG-0700 \\
(Rev. 3) \\
Guideline \\
Number
\end{tabular} & Guideline Title & Explanation & $\begin{array}{c}\text { Comply } \\
\text { (Y/N/NA/U) }\end{array}$ & Comments \\
\hline $1.1-14$ & Status at a Glance & $\begin{array}{l}\text { Information display systems should allow users to immediately } \\
\text { assess overall plant status and detect conditions that require } \\
\text { attention without performing interface management tasks. (In } \\
\text { practice this means that at least key performance indicators } \\
\text { ([KPIs] must always be visible). }\end{array}$ & Y & The Overview has three KPIs for status at a glance \\
\hline $1.1-15$ & Actual System/Equipment Status & $\begin{array}{l}\text { Indications of the actual status of plant systems and equipment, } \\
\text { as opposed to demand status, should be provided when } \\
\text { required by the task. }\end{array}$ & Y & $\begin{array}{l}\text { Might want to have the demand values for the control vales } \\
\text { accessible in some form }\end{array}$ \\
\hline $1.1-16$ & $\begin{array}{l}\text { Display of Parameters and Variables } \\
\text { Important to Safety }\end{array}$ & $\begin{array}{l}\text { Plant parameters and variables important to safety should be } \\
\text { displayed in a way that is convenient and readily accessible. }\end{array}$ & $\mathrm{N}$ & $\begin{array}{l}\text { Need to define normal operating ranges for the } \\
\text { instrumentation when the system is warming up and online }\end{array}$ \\
\hline $1.1-17$ & Normal Value Reference Index & $\begin{array}{l}\text { Displays should contain references to the values of normal } \\
\text { operating conditions. }\end{array}$ & N & \\
\hline $1.1-18$ & Critical Value Reference Index & $\begin{array}{l}\text { A display should include a reference index when the user must } \\
\text { compare displayed information with some critical value. } \\
\text { Additional Information: Indexing may be complicated in some } \\
\text { situations, such as when a series of bar charts do not have a } \\
\text { common measure. In such a case, it might help to use an index } \\
\text { scheme such that bar lengths will fall in the same zone under }\end{array}$ & $\mathrm{N}$ & $\begin{array}{l}\text { The setpoint and process variable values on the controllers } \\
\text { could be depicted as horizontal bars for easier reference. } \\
\text { Maybe not something exactly as depicted. But something } \\
\text { along those lines. }\end{array}$ \\
\hline $1.1-19$ & Limit Marks for Critical Variables & $\begin{array}{l}\text { Limit marks should be used to indicate operational limits for } \\
\text { critical plants parameters. }\end{array}$ & $\mathrm{N}$ & Need to define these \\
\hline
\end{tabular}

As stated above, this evaluation focused on the static elements only with dynamic elements such as alarms being marked unsure or not compliant due to the absence of such functions. The completion of these dynamic components will be done in a later report. Roughly $50 \%$ of the guidelines identified as relevant to the system were in the dynamic category. General evaluations of the interface were largely positive with no identification of any unclear static interface aspects and the organizational and readability components of the evaluation found that the interface was well designed in both cases. One potential flaw in this method is that the two human factors team members who completed the evaluation were involved in the initial and iterative designs. This familiarity may have led to overlooking some problematic aspects of the design due to their fundamental understanding of the system. Future evaluations will make use of evaluators outside of the immediate design team to ensure rating reliability.

A key reason to complete a robust expert evaluation step during the initial design iterations is to systematically identify areas of improvement for your design. Performing this task from a set of guidelines or heuristics, NUREG-0700 in this instance, further ensures that many of the more mundane aspects are not misses in the overall design, for example consistency in spacings and font sizes. Below is a table showing some selected design improvements that resulted from the expert evaluation findings. 
Table 4. Selected design changes from NUREG-0700 guideline review of the SEL HSI

\begin{tabular}{|c|c|c|}
\hline Design Recommendation & $\begin{array}{c}\text { Dispositioned } \\
\text { (Y/N/TBD) }\end{array}$ & Disposition/Comment \\
\hline Add time scales to sparklines & $\mathrm{Y}$ & On hover \\
\hline Ranges to bar charts & $\mathrm{Y}$ & Iterate for clutter and legibility \\
\hline Add demand values to controls & $\mathrm{Y}$ & Added to control screen \\
\hline Add line weight to flow paths & $\mathrm{Y}$ & \\
\hline Numerical data in P\&ID & $\mathrm{N}$ & Not enough room/clutter problem \\
\hline Add 'on hover' functionality to P\&ID & $\mathrm{Y}$ & \\
\hline Label heat exchangers in P\&ID & $\mathrm{Y}$ & \\
\hline $\begin{array}{l}\text { Validate work choice for labels, } \\
\text { controls, etc. }\end{array}$ & TBD & Will be evaluated during operator review \\
\hline Add levels for both heat exchanger & $\mathrm{Y}$ & \\
\hline Add instrumentation for separator & $\mathrm{Y}$ & \\
\hline Update controllers on controls screen & $\mathrm{Y}$ & \\
\hline $\begin{array}{l}\text { Identify heat exchanger and separator } \\
\text { venting }\end{array}$ & $\mathrm{Y}$ & Valve states added \\
\hline Add display of adjusted Tref & $\mathrm{Y}$ & \\
\hline $\begin{array}{l}\text { Define ranges for instruments and } \\
\text { indicators }\end{array}$ & TBD & \\
\hline Define critical variables and values & TBD & \\
\hline $\begin{array}{l}\text { Numeric values should be displayed to } \\
\text { show valve positions }\end{array}$ & TBD & Implement on mouseover \\
\hline Match font size of tables and P\&ID & $\mathrm{Y}$ & \\
\hline $\begin{array}{l}\begin{array}{l}\text { Create legend and training } \\
\text { iconography }\end{array} \\
\end{array}$ & TBD & \\
\hline Addition of arrows to flow line & $\mathrm{Y}$ & \\
\hline $\begin{array}{l}\text { Lowercase "L" and capital "I" look } \\
\text { similar }\end{array}$ & TBD & $\begin{array}{c}\text { We need to evaluate other font options or } \\
\text { mitigative steps }\end{array}$ \\
\hline Auditory alarms & TBD & \\
\hline $\begin{array}{l}\text { For automated trips show the first out } \\
\text { somewhere on the overview. E.g. } \\
\text { HTSE tripped on low EHX-1 Shell } \\
\text { Level }\end{array}$ & TBD & \\
\hline Different colors on alarm tiles & $\mathrm{Y}$ & \\
\hline $\begin{array}{l}\text { Users should be able to access } \\
\text { individual alarms that are in group } \\
\text { alarm }\end{array}$ & TBD & \\
\hline Actual status vs demand status & $\mathrm{Y}$ & \\
\hline Identify safety parameters and limits & TBD & \\
\hline Develop coding/highlighting plan & TBD & \\
\hline Reference points need added & TBD & \\
\hline Error message development & TBD & \\
\hline Undo and backup workflow & TBD & \\
\hline Alarm system development & TBD & \\
\hline Add time stamps & TBD & \\
\hline Entry and validation dialogs & TBD & \\
\hline
\end{tabular}




\subsubsection{Operator Review}

The team engaged with two operator teams to evaluate and give feedback for future designs. One challenge that quickly presented itself is the large amount that operators rely on their understandings of the system characteristics to give feedback on specific design ideas. Due to the fact that this system is hypothetical and a novel idea within a control room concept, there was some difficulty for the operators to speak to actual usability, overall experience, and needs within that context. However, there were some key findings that were similar across the two operator teams. First, was the need for more delta-style indicators that showed the state of flow and pressure in a section rather than overall absolute system values. Second, there was a preference to show a P\&ID display or some other component map somewhere in the design. One aspect of the design that was met with mixed reviews was the level of automation in control actions. There was a concession regarding the simplicity of the system and the idea that as long as the operators had transparency into the actions and system states then there is not necessarily a need for operators to perform every action manually. However, there is a need for further research and validation of these concepts before a determination can be made. The results of the expert review and the operator review were incorporated into the final design presented in a subsequent section. 


\section{Finalized HSI Design}

A finalized design for the SEL indication display (see Figure 10) was developed based on the human factors and operator reviews described in the previous sections. The display regions were organized based on the layout specifications from Figure 4, and contain the following elements:

- Alarms occupied the top of the display

- Prominent parameters were arranged in a ribbon directly below the alarms

- A P\&ID of the primary elements of the SEL was displayed in the middle

- Tables of parameters pertaining to loop discharge and return and heat exchanged for the thermal energy dispatch arranged along the sides of the P\&ID

- Buttons along the bottom support navigation between displays.

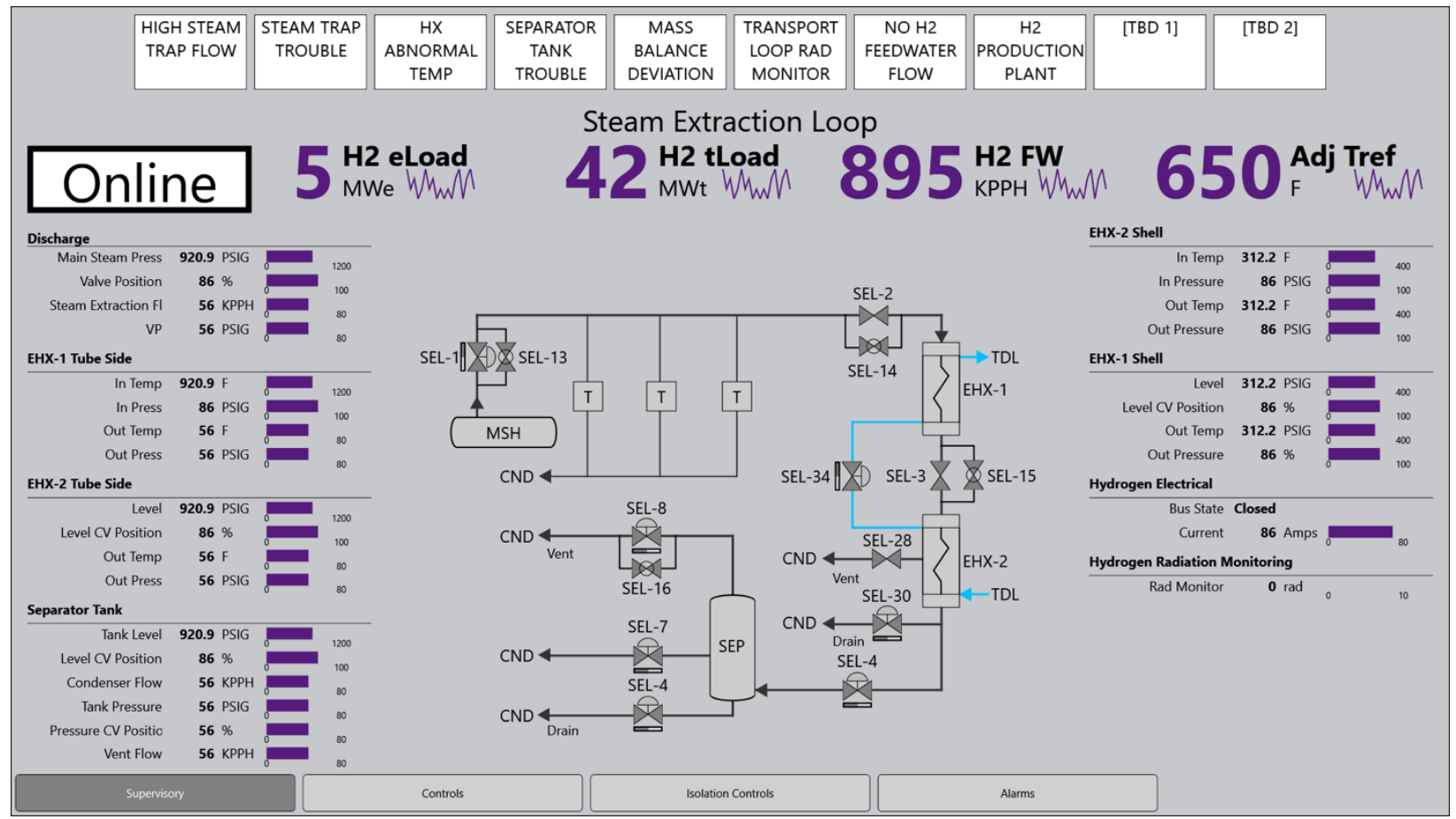

Figure 10. Finalized design of the steam extraction loop indication display incorporating the operator and expert reviews. 

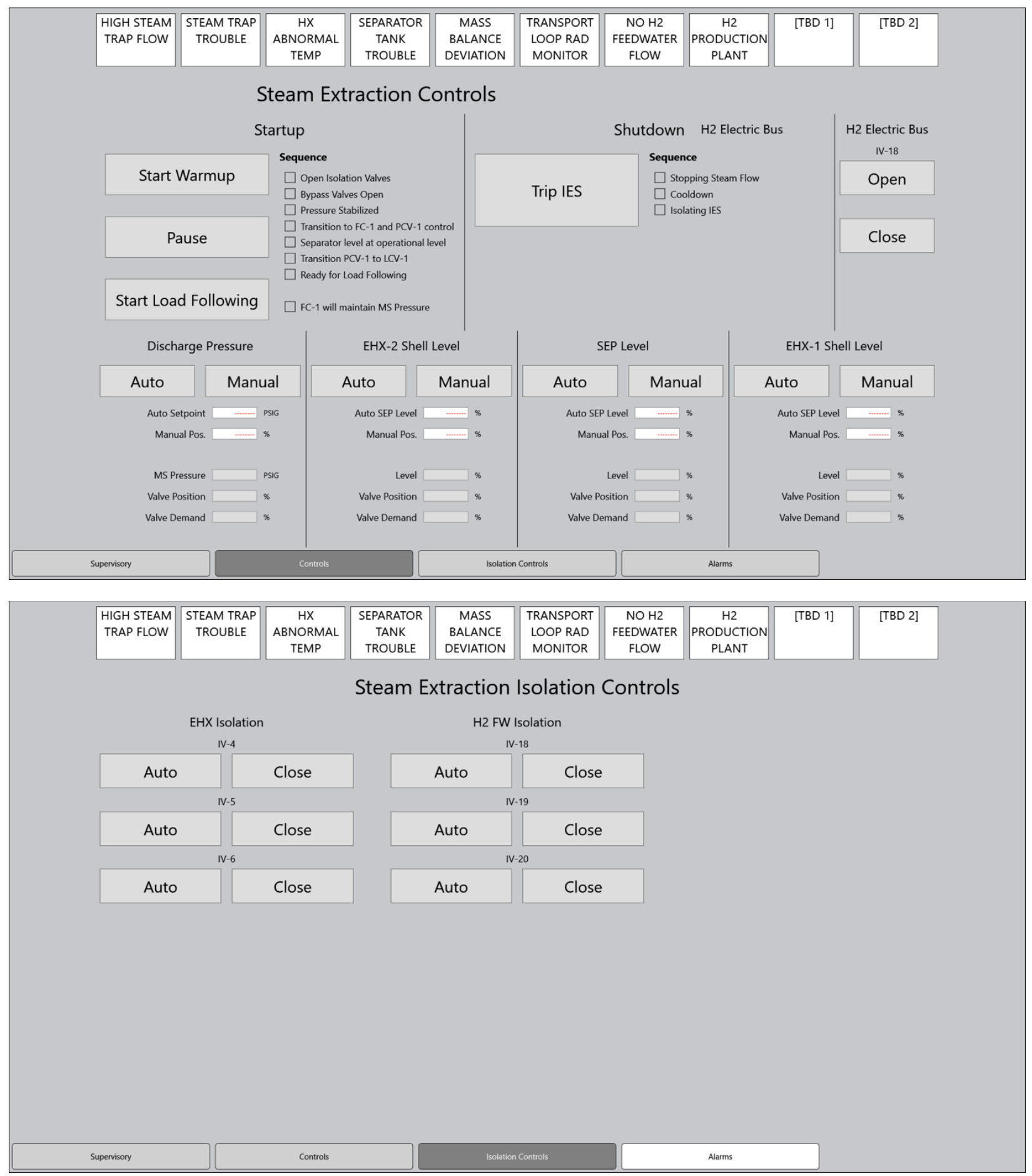

Figure 11. Finalized design of the steam extraction loop control displays incorporating the operator and expert reviews. The top display pertains to the main controls and the bottom display contains the controls for isolating the steam extraction loop.

The main control displays (see Figure 11, top) also follows a similar layout; however, instead of a P\&ID occupying the bulk of the display, the center area of the display contains the task based 
regions for performing evolutions with permissive displays that depict the current state in the evolution. The bottom region is populated with controllers for each of the controllable valves and the one electrical bus in the system. A separate SEL isolation control display was added after as a result of an engineering update to the system comprised of two additional flow controllers for the heat exchangers (see Figure 11, bottom). This further congested the control display. Because the isolation valves are envisioned to be used only during abnormal operations to isolate the SEL system, the controls for the isolation were placed on their own dedicated display.

\section{Integration with GPWR}

The HSI static mockups were implemented in Windows Presentation Foundation (WPF) using our Advanced Nuclear Interface Modeling Environment (ANIME; Boring, Lew, and Ulrich, 2017). ANIME allows for fully functional HSI prototypes to be rapidly implemented and iterated. ANIME can be used to emulate the appearance and functionality of vendor HSI solutions. The HSI prototypes can be developed as standalone microworld simulators or integrated with fullscope simulators.

In a separate effort, a thermal hydraulic model of the SEL is being developed for the GPWR using simulator tools provided by the GSE simulator vendor. The SEL model will integrate with GPWR and contain all the components and instrumentation depicted in Figure 1. Two-way communication with the HSI prototype will be enabled through INL's GiiNET library. GiiNET is a .NET wrapper for GSE's Gii (S3dll) application programming interface (API). It allows network communication from .NET including WPF applications. Once the HSI has been integrated with the SEL thermal hydraulic model and GPWR, it can be deployed within the HSSL for more extensive evaluation and validation with full-scope scenario testing.

\section{Conclusions and Future Directions}

The fleet of NPPs in the U.S. is a valuable asset as part of our evolving energy portfolio. Each of our 98 operating reactors has a replacement value of roughly $\$ 10$ billion, implying a total fleet value of close to $\$ 1$ trillion. Despite their age, they have a remarkable track record of safety and have industry leading capacity factors that cannot be matched by renewables. License renewal and joint energy-hydrogen production are opportunities to provide clean energy and hydrogen for manufactured fertilizers and other industrial processes, all while increasing grid resilience. The HSI developed here will undergo operator-in-the-loop testing to demonstrate the feasibility of the joint electricity-hydrogen flexible operations and ensure the SEL can be operated safely and efficiently. Future work is proposed to perform this testing later this year. Upon successful completion to of the testing, recommendations to optimize the HSI will be provided and a revised interface will be developed as a template for utilities as they move forward with adopting flexible operations. Additional work may prove necessary to investigate different types of coupling with the SEL based on the needs of the attached process as other high heat production processes are also being targeted for potential business cases to boost the economic competitiveness of NPPs. 


\section{References}

Al Rashdan, A., Lew, R., Hanes, L., Kovesdi, C., Boring, R., Rice, B., \& Ulrich, T. (2017). The Operator Study on System Overviews (OSSO): Design Study for Digital Upgrades in Control Rooms with and Without Overview Screens. INL/EXT-17-43423.

Annett, J., Hierarchical task analysis. Handbook of cognitive task design, 2003. 2: p. 17-35.

Boring, R.L., Lew, R., Thomas, K.D. \& Ulrich, T. (2015). Computerized Operator Support Systems for Aid Decision Making in Nuclear Power Plants. Procedia Manufacturing, 3, 5261-5268.

Boring, R., Lew, R., and Ulrich, T. (2017). Advanced nuclear interface modeling environment (ANIME): A tool for developing human-computer interfaces for experimental process control systems. Lecture Notes in Computer Science, 10293, 3-15.

Boring, R. L., Ulrich, T. A., Joe, J. C., \& Lew, R. T. (2015). Guideline for operational nuclear usability and knowledge elicitation (GONUKE). Procedia Manufacturing, 3, 1327-1334.

Boring, R. L., Lew, R., \& Ulrich, T. A. (2016, September). Epistemiation: An approach for knowledge elicitation of expert users during product design. In Proceedings of the Human Factors and Ergonomics Society Annual Meeting (Vol. 60, No. 1, pp. 1701-1705). Sage CA: Los Angeles, CA: SAGE Publications.

Boring, R., Ulrich, T., Lew, R., Kovesdi, C., Rice, B., Poresky, C., ... \& Savchenko, K. (2017). Analog, digital, or enhanced human-system interfaces? results of an operator-in-the-loop study on main control room modernization for a nuclear power plant (No. INL/EXT-1743188-Rev000). Idaho National Lab.(INL), Idaho Falls, ID (United States).

Lew, R., Ulrich, T., Boring, R., and Thomas, K. (2014). A functional prototype for a computerized operator support system. Proceedings of the International Symposium on Resilient Control Systems (Resilience Week).

O'Hara, J., Higgins J., and Fleger, S. (2012). Human factors engineering program review model (NUREG-0711) revision 3: update methodology and key revisions. Brookhaven National Laboratory (BNL).

Pulliam, R., et al. (1983). Methodology for allocating nuclear power plant control functions to human or automatic control (NUREG/CR-3331). Washington DC: US Nuclear Regulatory Commission.

Ulrich, T. A., Lew, R., Boring, R. L., \& Thomas, K. (2014, September). A computerized operator support system prototype. In Proceedings of the Human Factors and Ergonomics Society Annual Meeting (Vol. 58, No. 1, pp. 1899-1903). Sage CA: Los Angeles, CA: SAGE Publications.

U.S. Nuclear Regulatory Commission. (2019). Human Interface Design Review Guidelines (NUREG-700) revision 3. Washington DC: US Nuclear Regulatory Commission. 


\section{Appendix A}

\section{Results of the FRA and FA}

\begin{tabular}{|c|c|c|c|c|c|c|c|}
\hline \multicolumn{5}{|c|}{ Functional requirements analysis } & \multicolumn{3}{|c|}{ Function allocation } \\
\hline Goal & Function & Success path & Controlled component & Controlled parameter & $\begin{array}{c}\text { Auto } \\
\text { initiation }\end{array}$ & $\begin{array}{c}\text { Manual } \\
\text { initiation }\end{array}$ & $\begin{array}{l}\text { Control } \\
\text { mode }\end{array}$ \\
\hline \multirow{8}{*}{$\begin{array}{l}\text { Produce } \\
\text { hydrogen }\end{array}$} & \multirow{5}{*}{$\begin{array}{l}\text { Main steam } \\
\text { supply }\end{array}$} & $\begin{array}{l}\text { Main feed-water } \\
\text { supply }\end{array}$ & $\begin{array}{l}\text { Booster pump, feed-water } \\
\text { pump, feed-water heater }\end{array}$ & $\begin{array}{l}\text { Feed-water flow rate, feed-water } \\
\text { temperature, feed-water pressure }\end{array}$ & $\mathrm{N}$ & $\mathrm{Y}$ & Manual \\
\hline & & $\begin{array}{l}\text { Feed-water } \\
\text { control system }\end{array}$ & $\begin{array}{l}\text { Main feed water isolation } \\
\text { valve, economizer control } \\
\text { valve, down-comer control } \\
\text { valve }\end{array}$ & Feed-water flow rate & $\mathrm{Y}$ & $\mathrm{Y}$ & AAM \\
\hline & & $\begin{array}{l}\text { Steam control in } \\
\text { IES }\end{array}$ & $\begin{array}{l}\text { Flow rate control valve, } \\
\text { bypass valve, isolation valve, } \\
\text { atmospheric dumping valve }\end{array}$ & Flow rate & $\mathrm{N}$ & $\mathrm{Y}$ & Manual \\
\hline & & Pressure control & Pressurizer in IES & Flow rate, SEL pressure & $\mathrm{Y}$ & $\mathrm{Y}$ & AAM \\
\hline & & $\begin{array}{l}\text { Steam separate } \\
\text { system }\end{array}$ & Steam trap & $\begin{array}{l}\text { Steam inventory, condensed } \\
\text { water inventory, steam flow rate, } \\
\text { steam temperature, steam quality }\end{array}$ & $\mathrm{N}$ & $\mathrm{Y}$ & Manual \\
\hline & $\begin{array}{l}\text { Electricity } \\
\text { supply }\end{array}$ & $\begin{array}{l}\text { Electricity } \\
\text { dsupply from } \\
\text { non-class 1E bus }\end{array}$ & Non-1E bus transformer & $\begin{array}{l}\text { Hydrogen production rate, } \\
\text { voltage or amp of Non-1E bus }\end{array}$ & $\mathrm{N}$ & $\mathrm{Y}$ & Manual \\
\hline & \multirow[t]{2}{*}{$\begin{array}{l}\text { Condensed } \\
\text { inventory } \\
\text { circulation }\end{array}$} & $\begin{array}{l}\text { Condensed } \\
\text { water circulation } \\
\text { to condenser } \\
\end{array}$ & $\begin{array}{l}\text { Isolation valve, flow control } \\
\text { valve, atmospheric dumping } \\
\text { valve, bypass valve }\end{array}$ & Flow rate & $\begin{array}{l}\text { Pressure in } \\
\text { IES }\end{array}$ & $\mathrm{Y}$ & AXM \\
\hline & & Pressure control & Pressurizer in IES & Flow rate, SEL pressure & $\mathrm{Y}$ & $\mathrm{Y}$ & AAM \\
\hline $\begin{array}{l}\text { Ensure } \\
\text { safety }\end{array}$ & $\begin{array}{l}\text { System } \\
\text { isolation }\end{array}$ & $\begin{array}{l}\text { Penetration flow } \\
\text { path control }\end{array}$ & $\begin{array}{l}\text { Isolation valve, flow rate } \\
\text { control valve, atmospheric } \\
\text { dumping valve }\end{array}$ & Flow rate & $\mathrm{Y}$ & $\mathrm{Y}$ & AAM \\
\hline
\end{tabular}




\section{Appendix B}

\section{Results of the Task Analysis}

\begin{tabular}{|c|c|c|c|c|c|c|c|c|}
\hline No. & Task & Sub-tasks & Task verb & Task device & $\begin{array}{l}\text { Task } \\
\text { charac }\end{array}$ & $\begin{array}{l}\text { vice } \\
\text { ristic }\end{array}$ & $\begin{array}{l}\text { Influential } \\
\text { parameter }\end{array}$ & Output \\
\hline \multirow{6}{*}{1} & \multirow{6}{*}{$\begin{array}{l}\text { Supply } \\
\text { main feed- } \\
\text { water }\end{array}$} & \multirow{3}{*}{$\begin{array}{l}\text { Identify whether main } \\
\text { feed-water is supplied }\end{array}$} & \multirow{3}{*}{ Identify } & Booster pump & State & Turn on & \multirow{3}{*}{$\mathrm{N} / \mathrm{A}$} & \multirow{3}{*}{$\begin{array}{l}\text { The state for main } \\
\text { feed-water supply is } \\
\text { identified. }\end{array}$} \\
\hline & & & & Feed-water pump & State & Turn on & & \\
\hline & & & & Feed-water heaters & State & Turn on & & \\
\hline & & Operate booster pump & Operate & Booster pump & State & Turn on & \multirow{3}{*}{$\begin{array}{l}\text { Feed-water flow rate, } \\
\text { Feed-water } \\
\text { temperature, Feed- } \\
\text { water pressure }\end{array}$} & \multirow{3}{*}{$\begin{array}{l}\text { Main feed-water is } \\
\text { supplied. }\end{array}$} \\
\hline & & Feed-water pump & Operate & Feed-water pump & State & Turn on & & \\
\hline & & Feed-water heater & Operate & Feed-water heater & State & Turn on & & \\
\hline \multirow{5}{*}{2} & \multirow{5}{*}{$\begin{array}{l}\text { Control } \\
\text { feed-water } \\
\text { flow rate }\end{array}$} & $\begin{array}{l}\text { Identify feed-water } \\
\text { control system operates } \\
\text { automatically }\end{array}$ & Identify & Automation & State & Turn on & $\mathrm{N} / \mathrm{A}$ & $\begin{array}{l}\text { Whether the feed- } \\
\text { water control } \\
\text { automation operates } \\
\text { automatically is } \\
\text { identified. }\end{array}$ \\
\hline & & $\begin{array}{l}\text { Manipulate main feed } \\
\text { water isolation valve }\end{array}$ & Manipulate & $\begin{array}{l}\text { Main feed water } \\
\text { isolation valve }\end{array}$ & $\begin{array}{l}\text { Continuous } \\
(0 \sim 100 \%)\end{array}$ & $>0$ & \multirow{3}{*}{ Feed-water flow rate } & \multirow{4}{*}{$\begin{array}{l}\text { The feed-water flow } \\
\text { rate is controlled. }\end{array}$} \\
\hline & & $\begin{array}{l}\text { Manipulate economizer } \\
\text { control valve }\end{array}$ & Manipulate & $\begin{array}{l}\text { Economizer control } \\
\text { valve }\end{array}$ & $\begin{array}{l}\text { Continuous } \\
(0 \sim 100 \%)\end{array}$ & $>0$ & & \\
\hline & & $\begin{array}{l}\text { Manipulate down- } \\
\text { comer control valve }\end{array}$ & Manipulate & $\begin{array}{l}\text { Down-comer } \\
\text { control valve }\end{array}$ & $\begin{array}{l}\text { Continuous } \\
(0 \sim 100 \%)\end{array}$ & $>0$ & & \\
\hline & & $\begin{array}{l}\text { Identify feed-water } \\
\text { control system operates }\end{array}$ & Identify & Feed-water flow rate & Continuous & $>0$ & $\mathrm{~N} / \mathrm{A}$ & \\
\hline \multirow{3}{*}{3} & \multirow{3}{*}{$\begin{array}{l}\text { Control } \\
\text { steam flow } \\
\text { rate in IES }\end{array}$} & $\begin{array}{l}\text { Manipulate Isolation / } \\
\text { bypass valve }\end{array}$ & Manipulate & $\begin{array}{l}\text { Isolation / bypass } \\
\text { valve }\end{array}$ & $\begin{array}{l}\text { Continuous } \\
(0 \sim 100 \%)\end{array}$ & $>0$ & \multirow{3}{*}{ Flow rate } & \multirow{3}{*}{$\begin{array}{l}\text { Steam flow rate in } \\
\text { SEL is controlled. }\end{array}$} \\
\hline & & $\begin{array}{l}\text { Manipulate flow rate } \\
\text { control valve }\end{array}$ & Manipulate & $\begin{array}{l}\text { Flow rate control } \\
\text { valve }\end{array}$ & $\begin{array}{l}\text { Continuous } \\
(0 \sim 100 \%)\end{array}$ & $>0$ & & \\
\hline & & $\begin{array}{l}\text { Manipulate atmospheric } \\
\text { dumping valve }\end{array}$ & Manipulate & $\begin{array}{l}\text { Atmospheric } \\
\text { dumping valve }\end{array}$ & $\begin{array}{l}\text { Continuous } \\
(0 \sim 100 \%)\end{array}$ & $>0$ & & \\
\hline
\end{tabular}




\begin{tabular}{|c|c|c|c|c|c|c|c|c|}
\hline & & Identify steam flow rate & Identify & Steam flow rate & Continuous & $>0$ & $\mathrm{~N} / \mathrm{A}$ & \\
\hline \multirow{3}{*}{4} & \multirow{3}{*}{$\begin{array}{l}\text { Control } \\
\text { pressure to } \\
\text { make a } \\
\text { steam flow } \\
\text { rate }\end{array}$} & $\begin{array}{l}\text { Identify whether a } \\
\text { pressurizer in SEL } \\
\text { operates automatically }\end{array}$ & Identify & Automation & State & Turn on & N/A & \multirow{3}{*}{$\begin{array}{l}\text { Flow rate due to the } \\
\text { pressure is made. }\end{array}$} \\
\hline & & $\begin{array}{l}\text { Manipulate a } \\
\text { pressurizer in IES }\end{array}$ & Manipulate & A pressurizer in IES & $\begin{array}{l}\text { Continuous } \\
(0 \sim 100 \%)\end{array}$ & $>0$ & $\begin{array}{l}\text { Flow rate, SEL } \\
\text { pressure }\end{array}$ & \\
\hline & & $\begin{array}{l}\text { Identify steam flow rate } \\
\text { / pressure }\end{array}$ & Identify & $\begin{array}{l}\text { Steam flow rate / } \\
\text { pressure }\end{array}$ & Continuous & $>0$ & N/A & \\
\hline 5 & $\begin{array}{l}\text { Control } \\
\text { flow rate in } \\
\text { steam } \\
\text { separate } \\
\text { system }\end{array}$ & $\begin{array}{l}\text { Control flow rate using } \\
\text { isolation values in steam } \\
\text { separate system }\end{array}$ & Manipulate & Isolation valve & $\begin{array}{l}\text { Continuous } \\
(0 \sim 100 \%)\end{array}$ & $>0$ & Flow rate & $\begin{array}{l}\text { Flow rate is } \\
\text { controlled. }\end{array}$ \\
\hline \multirow[t]{2}{*}{6} & \multirow{2}{*}{$\begin{array}{l}\text { Supply } \\
\text { electricity } \\
\text { to start } \\
\text { hydrogen } \\
\text { production }\end{array}$} & $\begin{array}{l}\text { Close Non-1E bus } \\
\text { transformer }\end{array}$ & Manipulate & $\begin{array}{l}\text { Non-1E } \quad \text { bus } \\
\text { transformer }\end{array}$ & State & Close & $\begin{array}{l}\text { Hydrogen production } \\
\text { rate, voltage or amp of } \\
\text { Non-1E bus }\end{array}$ & \multirow{2}{*}{$\begin{array}{l}\text { According to the } \\
\text { Non-1E bus } \\
\text { connected, hydrogen } \\
\text { is produced. }\end{array}$} \\
\hline & & $\begin{array}{ll}\text { Identify } & \text { hydrogen } \\
\text { production } & \\
\end{array}$ & Identify & $\begin{array}{l}\text { Hydrogen } \\
\text { production rate }\end{array}$ & Continuous & $>0$ & N/A & \\
\hline \multirow{5}{*}{7} & \multirow{5}{*}{$\begin{array}{l}\text { Circulate } \\
\text { condensed } \\
\text { water to } \\
\text { condenser }\end{array}$} & $\begin{array}{l}\text { Identify whether } \\
\text { condensed } \quad \text { water } \\
\text { automatically circulates }\end{array}$ & Identify & Automation & State & Turn on & N/A & \multirow{5}{*}{$\begin{array}{l}\text { Condensed water is } \\
\text { circulated. }\end{array}$} \\
\hline & & $\begin{array}{l}\text { Manipulate isolation } \\
\text { valve }\end{array}$ & Manipulate & Isolation valve & $\begin{array}{l}\text { Continuous } \\
(0 \sim 100 \%)\end{array}$ & $>0$ & Flow rate & \\
\hline & & $\begin{array}{l}\text { Manipulate flow control } \\
\text { / bypass valve }\end{array}$ & Manipulate & $\begin{array}{l}\text { Flow control / } \\
\text { bypass valve }\end{array}$ & $\begin{array}{l}\text { Continuous } \\
(0 \sim 100 \%)\end{array}$ & $>0$ & Flow rate & \\
\hline & & $\begin{array}{l}\text { Manipulate atmospheric } \\
\text { dumping valve }\end{array}$ & Manipulate & $\begin{array}{l}\text { Atmospheric } \\
\text { dumping valve }\end{array}$ & $\begin{array}{l}\text { Continuous } \\
(0 \sim 100 \%)\end{array}$ & $>0$ & Flow rate & \\
\hline & & Identify flow rate & Identify & Flow rate & Continuous & $>0$ & $\mathrm{~N} / \mathrm{A}$ & \\
\hline \multirow{3}{*}{8} & \multirow{3}{*}{$\begin{array}{l}\text { Control } \\
\text { pressure to } \\
\text { make a } \\
\text { steam flow } \\
\text { rate }\end{array}$} & $\begin{array}{l}\text { Identify whether a } \\
\text { pressurizer in SEL } \\
\text { operates automatically }\end{array}$ & Identify & Automation & State & Turn on & N/A & \multirow{3}{*}{$\begin{array}{l}\text { Flow rate due to the } \\
\text { pressure is made. }\end{array}$} \\
\hline & & $\begin{array}{l}\text { Manipulate } \\
\text { pressurizer in IES }\end{array}$ & Manipulate & A pressurizer in IES & $\begin{array}{l}\text { Continuous } \\
(0 \sim 100 \%)\end{array}$ & $>0$ & $\begin{array}{l}\text { Flow rate, SEL } \\
\text { pressure }\end{array}$ & \\
\hline & & Identify steam flow rate & Identify & Steam flow rate & Continuous & $>0$ & $\mathrm{~N} / \mathrm{A}$ & \\
\hline \multirow{2}{*}{9} & \multirow{2}{*}{ Isolate IES } & $\begin{array}{l}\text { Identify SEL is } \\
\text { automatically isolated }\end{array}$ & Identify & Automation & State & Turn on & N/A & \multirow{2}{*}{ IES is isolated. } \\
\hline & & $\begin{array}{l}\text { Manipulate isolation } \\
\text { valve }\end{array}$ & Manipulate & Isolation valve & $\begin{array}{l}\text { Continuous } \\
(0 \sim 100 \%)\end{array}$ & $>0$ & Flow rate & \\
\hline
\end{tabular}




\begin{tabular}{|l|l|l|l|l|l|l|l|}
\hline & $\begin{array}{l}\text { Manipulate flow rate } \\
\text { control / atmospheric } \\
\text { dumping valve }\end{array}$ & Manipulate & $\begin{array}{l}\text { Flow rate control / } \\
\text { atmospheric } \\
\text { dumping valve }\end{array}$ & $\begin{array}{l}\text { Continuous } \\
(0 \sim 100 \%)\end{array}$ & $>0$ & Stentify whether SEL is \\
\cline { 2 - 6 } & Identify & IES isolation & State & Isolation & N/A \\
\hline
\end{tabular}




\section{Appendix C}

\section{A list of components identified from the result of FRA, FA and TA}

\begin{tabular}{|c|c|c|c|c|c|}
\hline Goal & Task & Task device & $\begin{array}{c}\text { Component required to be in } \\
\text { HSI }\end{array}$ & $\begin{array}{l}\text { Component } \\
\text { design type }\end{array}$ & Recommended shape in HSI \\
\hline \multirow{20}{*}{ Produce hydrogen } & \multirow{6}{*}{$\begin{array}{l}\text { Supply main } \\
\text { feed-water }\end{array}$} & Booster pump & \multirow{3}{*}{$\begin{array}{l}\text { A signal showing main feed-water } \\
\text { is under operation }\end{array}$} & \multirow{3}{*}{$\begin{array}{l}\text { Indicator or } \\
\text { alarm }\end{array}$} & \multirow{3}{*}{$\begin{array}{l}\text { Circle (Green/Red) or alarm } \\
\text { panel }\end{array}$} \\
\hline & & Feedwater pump & & & \\
\hline & & Feedwater heater & & & \\
\hline & & Feedwater flow rate & Feedwater flow rate & \multirow{3}{*}{ Indicator } & \multirow{3}{*}{ Integrated design (triangle) } \\
\hline & & Feedwater temperature & Feedwater temperature & & \\
\hline & & Feedwater pressure & Feedwater pressure & & \\
\hline & \multirow{5}{*}{$\begin{array}{l}\text { Control feed- } \\
\text { water flow rate }\end{array}$} & $\begin{array}{l}\text { Main feed water isolation } \\
\text { valve }\end{array}$ & \multirow{5}{*}{ Feed-water flow rate } & \multirow{5}{*}{$\begin{array}{l}\text { Indicator or } \\
\text { alarm }\end{array}$} & \multirow{5}{*}{$\begin{array}{l}\text { Value (continuous) or alarm } \\
\text { panel }\end{array}$} \\
\hline & & Economizer control valve & & & \\
\hline & & Down-comer control valve & & & \\
\hline & & Feed-water flow valve & & & \\
\hline & & Feed-water flow rate & & & \\
\hline & \multirow{5}{*}{$\begin{array}{l}\text { Control steam } \\
\text { flow rate in IES }\end{array}$} & Isolation valve & SEL-2, SEL-3 & $\begin{array}{l}\text { Controllable } \\
\text { component }\end{array}$ & Valve (Green/Red) \\
\hline & & Bypass valve & SEL-13, SEL-14 & $\begin{array}{l}\text { Controllable } \\
\text { component }\end{array}$ & Slider $(0 \% \sim 100 \%)$ \\
\hline & & Flow rate control valve & SEL-1, SEL-37, SEL-34, SEL-15 & $\begin{array}{l}\text { Controllable } \\
\text { component }\end{array}$ & Slider $(0 \% \sim 100 \%)$ \\
\hline & & $\begin{array}{l}\text { Atmospheric dumping } \\
\text { valve }\end{array}$ & SEL-36, SEP-29 & $\begin{array}{l}\text { Controllable } \\
\text { component }\end{array}$ & Slider $(0 \% \sim 100 \%)$ \\
\hline & & Steam flow rate & $\begin{array}{l}\text { Next to SEL-1, SEL-36, SEL-2, } \\
\text { SEL-29, SEL-3, SEL-34 }\end{array}$ & Indicator & Value (continuous) \\
\hline & \multirow{3}{*}{$\begin{array}{l}\text { Control pressure } \\
\text { to make a steam } \\
\text { flow rate }\end{array}$} & A pressurizer in IES & Next to SEL-1 & $\begin{array}{l}\text { Controllable } \\
\text { component }\end{array}$ & Slider $(0 \% \sim 100 \%)$ \\
\hline & & Steam flow rate & Next to SEL-1 & Indicator & Value (continuous) \\
\hline & & IES pressure & Next to SEL-1 & $\begin{array}{l}\text { Indicator or } \\
\text { alarm }\end{array}$ & Trend graph or alarm panel \\
\hline & & Non-1E bus transformer & $\begin{array}{l}\text { A signal showing Non-1E bus } \\
\text { transformer is connected }\end{array}$ & $\begin{array}{l}\text { Indicator or } \\
\text { alarm }\end{array}$ & $\begin{array}{l}\text { Circle (Green/Red) or alarm } \\
\text { panel }\end{array}$ \\
\hline
\end{tabular}




\begin{tabular}{|c|c|c|c|c|c|}
\hline & $\begin{array}{l}\text { Supply electricity } \\
\text { to start hydrogen } \\
\text { production }\end{array}$ & Hydrogen production rate & Between Hx and hydrogen loop & Indicator & Trend graph \\
\hline & \multirow{5}{*}{$\begin{array}{l}\text { Circulate } \\
\text { condensed water } \\
\text { to condenser }\end{array}$} & Isolation valve & $\begin{array}{l}\text { SEL-28, SEL-17, SEL-23, SEL- } \\
\text { 18, SEL-24, SEL-19, SEL-25, } \\
\text { SEL-12, SEL-6 }\end{array}$ & $\begin{array}{l}\text { Controllable } \\
\text { component }\end{array}$ & Valve (Green/Red) \\
\hline & & Flow control valve & $\begin{array}{l}\text { SEL-30, SEL-4, SEL-32, SEL-7, } \\
\text { SEL-8 }\end{array}$ & $\begin{array}{l}\text { Controllable } \\
\text { component }\end{array}$ & Slider $(0 \% \sim 100 \%)$ \\
\hline & & $\begin{array}{l}\text { Atmospheric dumping } \\
\text { valve }\end{array}$ & SEL-31 & $\begin{array}{l}\text { Controllable } \\
\text { component }\end{array}$ & Slider $(0 \% \sim 100 \%)$ \\
\hline & & Bypass valve & SEL-16 & $\begin{array}{l}\text { Controllable } \\
\text { component }\end{array}$ & Slider $(0 \% \sim 100 \%)$ \\
\hline & & Flow rate & $\begin{array}{l}\text { Next to SEL-11, SEL-12, SEL-30, } \\
\text { SEL-28, SEL-26, SEL-31 }\end{array}$ & Indicator & Value (continuous) \\
\hline & \multirow{3}{*}{$\begin{array}{l}\text { Control pressure } \\
\text { to make a steam } \\
\text { flow rate }\end{array}$} & A pressurizer in IES & Next to SEL-1 & $\begin{array}{l}\text { Controllable } \\
\text { component }\end{array}$ & Slider $(0 \% \sim 100 \%)$ \\
\hline & & Steam flow rate & Next to SEL-1 & Indicator & Value (continuous) \\
\hline & & IES pressure & Next to SEL-1 & Indicator & Trend graph \\
\hline \multirow{4}{*}{ Ensure safety } & \multirow{4}{*}{ Isolate IES } & Isolation valve & $\begin{array}{l}\text { SEL-2, SEL-3, SEL-28, SEL-17, } \\
\text { SEL-23, SEL-18, SEL-24, SEL- } \\
\text { 19, SEL-25, SEL-12, SEL-6 }\end{array}$ & $\begin{array}{l}\text { Controllable } \\
\text { component }\end{array}$ & Valve (Green/Red) \\
\hline & & Flow rate control valve & $\begin{array}{l}\text { SEL-1, SEL-37, SEL-34, SEL-15, } \\
\text { SEL-30, SEL-4, SEL-32, SEL-7, } \\
\text { SEL-8 }\end{array}$ & $\begin{array}{l}\text { Controllable } \\
\text { component }\end{array}$ & Slider $(0 \% \sim 100 \%)$ \\
\hline & & Flow rate & $\begin{array}{l}\text { Next to SEL-1, SEL-36, SEL-2, } \\
\text { SEL-29, SEL-3, SEL-34, SEL-11, } \\
\text { SEL-12, SEL-30, SEL-28, SEL- } \\
\text { 26, SEL-31 }\end{array}$ & Indicator & Value (continuous) \\
\hline & & $\begin{array}{l}\text { Atmospheric dumping } \\
\text { valve }\end{array}$ & SEL-36, SEP-29, SEL-31 & $\begin{array}{l}\text { Controllable } \\
\text { component }\end{array}$ & Slider $(0 \% \sim 100 \%)$ \\
\hline
\end{tabular}

